Article

\title{
Assessing the Magnitude and Likely Causes of Summertime Overheating in Modern Flats in UK
}

\author{
Rajat Gupta *(1) and Matt Gregg \\ Low Carbon Building Research Group, Oxford Institute for Sustainable Development, School of Architecture, \\ Oxford Brookes University, Oxford OX3 0BP, UK; p0020979@brookes.ac.uk \\ * Correspondence: rgupta@brookes.ac.uk
}

Received: 27 August 2020; Accepted: 27 September 2020; Published: 6 October 2020

\begin{abstract}
There has been increasing recognition that climate change may lead to risk of summertime overheating in UK dwellings with potentially adverse consequences for human comfort and health. This paper investigates the magnitude of summertime overheating over one month in 2017, in four new flats built to identical thermal standards, with similar occupancy patterns and located in the same block in a development in Southeast England. Both static and adaptive methods were used to assess the overheating risk, while the variation in indoor temperatures across the flats was examined through key building characteristics including floor level, glazing orientation, exposed surface area to floor area ratio (SA/FA), glazing area to floor area ratio, and ventilation. Data collection included continuous monitoring of indoor and outdoor temperature, relative humidity, $\mathrm{CO}_{2}$ levels and opening/closing of windows. Summertime overheating was found to be prevalent in all four flats but was most pronounced in two top floor flats with high SA/FA ratio and east/west facing glazing. Due to limited window opening and locational limitations of one flat, some conclusions were derived from three flats. Though the study sample is small, it is clear that overheating in new housing is a current issue and designing for avoidance of summertime overheating should become mainstream.
\end{abstract}

Keywords: overheating; housing; monitoring; survey; climate change

\section{Introduction}

Currently the UK is legally committed to net-zero emissions by 2050 [1] and to five-year carbon budgets in the interim set by the Committee on Climate Change (CCC) [2]. To meet this target in the housing sector, the UK government just completed a Future Homes Standard consultation which assessed future proofing of new dwellings through high levels of energy efficiency and integration of low carbon heating [3]. The Future Homes Standard is set for 2025, but consultation recommended incrementally moving towards the Standard by ramping up UK Building Regulations beginning in 2020 through conservation of heat and power, ventilation, and renewables. The principle is to improve the fabric performance of new dwellings as much as possible to avoid the need for short term retrofitting of the fabric which can be more costly and disruptive [4]. In addition, exploratory research projects and voluntary standards $[5,6]$ have successfully driven the development of more advanced levels of fabric and system efficiency in housing beyond UK building regulations. This will mean that thousands of new dwellings in the UK will be built with higher standards of insulation and greater airtightness with managed ventilation.

However, there is growing evidence of elevated indoor temperatures and risk of summertime overheating in existing homes [7-9] specifically bedrooms in semi-detached dwellings [10], as well as newer homes built to satisfy more demanding standards of energy efficiency [11,12], and modelled UK homes $[13,14]$. Though the term overheating is used to describe when higher temperatures make building occupants uncomfortable or heat stressed, it also has specific temperature thresholds, 
as explained later. With consecutive days of hot weather (including warmer than average nights), internal temperatures in some homes, particularly newer efficient homes, can start to exceed external temperatures and may no longer provide protection from the heat. These conditions can cause discomfort and heat-related effects on health of residents [15,16].

Furthermore, the impact of the Covid-19 pandemic on everyday life, for which we do not know the extent, could potentially lead to residents spending most of the time indoors. This could expose them to greater risk of overheating, especially during summertime. Hence mitigation of overheating has become more urgent. Good Homes Alliance in the UK has recently developed guidance to mitigate the overheating risk at the early design stage [17]. However, there is limited empirical evidence about the factors that exacerbate the risk of overheating in dwellings.

This paper adds to the empirical evidence base by systematically investigating the magnitude of summertime overheating and its likely causes in four new flats built to identical thermal standards, with similar occupancy patterns and located in the same block in a housing development in Southeast England. The variation in high indoor temperatures across the four flats was examined through key building characteristics including, location of the flat in terms of floor level, glazing orientation, exposed surface area to floor area ratio (SA/FA), glazing area to floor area ratio (GA/FA) and ventilation driven by window opening. In-situ and continuous monitoring of the indoor and outdoor temperature and relative humidity ( $\mathrm{RH})$, indoor $\mathrm{CO}_{2}$ levels, and open/closed status of window operation was carried out in each flat. Data on household characteristics and occupancy patterns were gathered using questionnaire surveys.

\section{Literature Review}

Much research has set out to establish the risk of overheating by simulating the current and future risk in older dwellings [18] and in newer dwellings [19] in different countries around the world. A number of studies have also demonstrated present-day monitored overheating or summer 'discomfort' in existing dwellings and newly built dwellings [12,20-23] in the UK and abroad, in Denmark [24], Austria [25], Sweden [26], and Estonia [27]. Within these studies the propensity to overheat is much greater in newer dwellings, e.g., Passivhaus designed dwellings, and particularly in flats. It is important to note that overheating is defined slightly differently from region to region, however, there is roughly an agreement that surpassing hours at $26-27^{\circ} \mathrm{C}$ is problematic.

In the UK, the commonly used overheating metrics are Standard Assessment Procedure (SAP), Passivhaus Planning Package (PHPP), The Chartered Institution of Building Services Engineers' (CIBSE) 'static method' [28] and 'adaptive method' from the CIBSE TM52 methodology [29] (derived from the adaptive thermal comfort ISO-EN 15251 standard [30]). The static method which defines upper limit thresholds for which a maximum percentage of occupied hours can exceed, has been used in a number of studies looking at simulated [31], existing [7], social housing [9], and Passivhaus dwellings [32]. EN 15251 has been used to evaluate thermal comfort in non-air-conditioned residential $[7,33]$ and non-residential buildings throughout Europe $[34,35]$. The Good homes Alliance tool and guidance on overheating in new homes [17] is intended to identify key factors contributing to overheating risk based on a check-list and possible mitigation measures. The tool is not meant to provide a detailed assessment, but instead to sit between existing high-level guidance for policy makers and detailed calculation and modelling tools.

Overheating can occur in homes as a result of several causes acting alone or together. These include heat gain from high external temperatures [36], higher localised temperatures exacerbated by the urban heat island (UHI) effect [25], direct solar gain on the exterior surface or penetrating glazing, and internal heat gains. Home characteristics such as dark surface materials, rooms in the roof, skylights, inability to ventilate due to location, predominately dark hard surface surroundings, single aspect flats on upper floors [37], and orientation that allows late solar gain in windows can all contribute to overheating [13]. For more vulnerable occupants, such as infants, the elderly or ill, the risk of severe heat stress, including potentially fatal heat stroke, is greater $[32,38]$. The cause of overheating is complex and not 
a simple measure of maximum temperatures; therefore, long continuous periods of above-average indoor temperatures in homes are used to evaluate this condition [29].

Table 1 lists a selection of overheating studies in new dwellings also with two low energy retrofit studies at the end. A common theme among them was the finding that the static method reveals a higher occurrence of overheating over the adaptive method; however, the adaptive method has been specifically designed for use in non-domestic buildings. Furthermore, CIBSE [39] cautions against the use of the adaptive criteria for assessing overheating in bedrooms because occupants have limited adaptive opportunity while in bed. For these reasons, though the adaptive method is observed, there is less weight given to the results in this paper.

Among the literature reviewed, there was also a recurring overheating performance gap in Passivhaus dwellings, i.e., a high occurrence of dwellings that failed the PHPP overheating criteria during as-built evaluations, indicating a possible failure in the model to predict the impact of construction or occupant behavior on overheating. There is some disagreement over the magnitude of the impact of occupant behavior vs. dwelling construction characteristics; however, the meeting of these two factors is a complex socio-technical issue in reality [40].

Design factors with significant impact on overheating include solar gain/lack of shading and lack of natural ventilation. As is noted above, these design factors; however, can also depend on occupant interaction. In low energy and Passivhaus buildings, not only do the design for better and easier to use ventilation and greater shading in summer (and even shoulder months [32]) need to be considered but there is a need to engage with occupants on how they can mitigate overheating. Examples of this are the importance of closing blinds to block solar gain, opening windows, and controlling mechanical ventilation (e.g., through summer bypass) [41,42].

To contribute to this body of knowledge, the objective of this study is to examine the magnitude of summertime overheating in four flats located in the same building in Southeast England. The likely causes of the variation in indoor temperatures are explained by investigating the impact of selected physical features such as location in terms of floor level, built form through surface area to floor area ratio, and window opening as an occupant-driven adaptive measure, on indoor temperatures. 
Table 1. Review of literature on overheating in new low energy dwellings.

\begin{tabular}{|c|c|c|c|c|}
\hline Citation & $\begin{array}{c}\text { Location } \\
\text { (No. of Dwellings and Significance) }\end{array}$ & Overheating Criteria & Focus of Study & Main Findings \\
\hline [42] & $\begin{array}{l}\text { UK-unknown urban location } \\
\text { (unspecified no. of flats) }\end{array}$ & Not specified & Causes of overheating & $\begin{array}{l}\text { Solar gains significant, more impact from communal } \\
\text { heating system distribution. Also lack of summer } \\
\text { bypass on MVHR and lack of window opening at } \\
\text { night due to proximity to railway. }\end{array}$ \\
\hline [43] & Dunblane, Scotland (2 dwellings) & Static [39] and Adaptive [30] & $\begin{array}{l}\text { Impact of orientation on } \\
\text { overheating }\end{array}$ & $\begin{array}{c}\text { Orientation is a significant modifying factor of } \\
\text { overheating. }\end{array}$ \\
\hline$[44,45]$ & $\begin{array}{l}\text { Scotland-multiple locations ( } 26 \text { low } \\
\text { energy and Passivhaus dwellings) }\end{array}$ & Static [39], SAP and PHPP & $\begin{array}{l}\text { Overheating as a relevant issue } \\
\text { in Scotland/demonstrating } \\
\text { current risk }\end{array}$ & $\begin{array}{l}\text { Northerly latitudes do not exempt low energy } \\
\text { buildings from overheating. Bedrooms were found to } \\
\text { be warmer compared to living rooms. Occupant } \\
\text { behaviour is a significant modifying factor of } \\
\text { overheating. }\end{array}$ \\
\hline [21] & $\begin{array}{c}\text { Coventry, England (18 flats and } 5 \\
\text { houses: Passivhaus) }\end{array}$ & Adaptive [29] and PHPP & $\begin{array}{l}\text { Overheating in high } \\
\text { performance flats }\end{array}$ & $\begin{array}{l}\text { Significant risk of summer overheating with more } \\
\text { than two-thirds of flats. Considerable difference in } \\
\text { overheating attributed to occupant behaviour rather } \\
\text { than construction. }\end{array}$ \\
\hline [40] & $\begin{array}{l}\text { Southeast England (6 dwellings CSH4 } \\
\text { \& CSH5) }\end{array}$ & Static [39] and Adaptive [29] & $\begin{array}{l}\text { Magnitude of overheating in } \\
\text { high performance dwellings }\end{array}$ & $\begin{array}{l}\text { High summer indoor temperature linked to window } \\
\text { opening patterns and underfloor heating faults. } \\
\text { Overheating linked to inter-related socio-technical } \\
\text { factors. }\end{array}$ \\
\hline [46] & $\begin{array}{l}\text { England-East Midlands \& Yorkshire } \\
\text { (4 low energy dwellings) }\end{array}$ & Static [39] & $\begin{array}{l}\text { Overheating in highly insulated } \\
\text { dwellings in the UK }\end{array}$ & $\begin{array}{l}\text { Absence of natural ventilation found to be significant } \\
\text { factor in overheating. Lack of solar control in general } \\
\text { leads to excessive heat gains and quick response in } \\
\text { temperature increase. }\end{array}$ \\
\hline [32] & $\begin{array}{l}\text { Sunderland, England (1 Passivhaus } \\
\text { dwelling) }\end{array}$ & $\begin{array}{c}\text { Static [39], Adaptive [29] and } \\
\text { PHPP }\end{array}$ & Vulnerable residents & $\begin{array}{l}\text { Measured temperatures substantially exceeded the } \\
\text { overheating prediction generated by PHPP. } \\
\text { Passivhaus dwellings can also cause the risk of } \\
\text { extending overheating risk outside of timeframe } \\
\text { expected, i.e., colder months. }\end{array}$ \\
\hline [12] & York, England (5-CSH4 dwellings) & Static [39] and Adaptive [29] & $\begin{array}{l}\text { Impact of occupants vs. } \\
\text { building characteristics on } \\
\text { overheating. }\end{array}$ & $\begin{array}{l}\text { Impact from occupant behaviour and internal gains, } \\
\text { though less influential than fabric construction on hea } \\
\text { gain and retention. }\end{array}$ \\
\hline$[47]$ & $\begin{array}{l}\text { UK-wide (60 low energy/Passivhaus } \\
\text { dwellings) }\end{array}$ & $\begin{array}{c}\text { Static [39], Adaptive [29] and } \\
\text { PHPP }\end{array}$ & $\begin{array}{l}\text { Large scale assessment of extent } \\
\text { of overheating in new } \\
\text { low-energy dwellings }\end{array}$ & $\begin{array}{l}\text { Overheating common in low energy dwellings-the } \\
\text { nature of overheating across different geographical } \\
\text { locations and seasons suggests that this is not just a } \\
\text { function of external conditions. }\end{array}$ \\
\hline
\end{tabular}


Table 1. Cont.

\begin{tabular}{ccccc}
\hline Citation & $\begin{array}{c}\text { Location } \\
\text { (No. of Dwellings and Significance) }\end{array}$ & Overheating Criteria & Focus of Study & Main Findings \\
\hline [38] & Loughborough, England (8 dwellings) & Static [39] and Adaptive [29] & $\begin{array}{c}\text { Overheating in } \\
\text { bungalows/vulnerability of } \\
\text { older residents }\end{array}$ & $\begin{array}{c}\text { Adaptive actions require physical and cognitive effort. } \\
\text { The most vulnerable to elevated temperatures may be } \\
\text { least able to take action. }\end{array}$ \\
\hline [48] & UK-wide (82 Passivhaus dwellings) & Adaptive [29] and PHPP & $\begin{array}{c}\text { Large-scale overheating risk } \\
\text { analysis of UK Passivhaus } \\
\text { dwellings }\end{array}$ & $\begin{array}{c}\text { Highly insulated dwellings such as Passivhaus should } \\
\text { consider overheating analysis in individual rooms, } \\
\text { rather than at whole-dwelling level. }\end{array}$ \\
\hline [41] & Leeds, England (18 deep retrofit flats) & Static [39] and Adaptive [29] & Overheating in flats & $\begin{array}{c}\text { Overheated due to lack of adequate shading for overly } \\
\text { large windows and poor ventilation. Occupants need } \\
\text { to be instructed on how to control overheating. }\end{array}$ \\
\hline [49] & $\begin{array}{c}\text { Rural Leicestershire, England (2 similar } \\
\text { dwellings one retrofitted with internal } \\
\text { wall insulation and one without) }\end{array}$ & Adaptive [29] & $\begin{array}{c}\text { Impact of internal wall } \\
\text { insulation (IWI) }\end{array}$ & $\begin{array}{c}\text { Night ventilation and shading brought the operative } \\
\text { temperature for the IWI dwelling down to that of the } \\
\text { non-insulated dwelling. }\end{array}$ \\
\hline
\end{tabular}




\section{Case Study and Methodology}

\subsection{Case Study Dwellings}

The four case study flats are a part of a recent housing development built in Southeast England; completed and occupied in 2017. The development is composed of a mix of housing typologies - townhouses, cottages, and flats — which surround a central courtyard lawn (Figure 1). The flats are occupied by residents with similar economic status (high income) and have all been designed with the same performance standards: wall U-value: $0.16 \mathrm{~W} / \mathrm{m}^{2} \mathrm{~K}$; roof U-value: $0.10 \mathrm{~W} / \mathrm{m}^{2} \mathrm{~K}$; floor U-value: $0.16 \mathrm{~W} / \mathrm{m}^{2} \mathrm{~K}$; window U-value: $1.4 \mathrm{~W} / \mathrm{m}^{2} \mathrm{~K}$; air permeability: $4 \mathrm{~m}^{3} / \mathrm{h} \cdot \mathrm{m}^{2} @ 50 \mathrm{~Pa}$. External walls are composed of one layer of concrete blocks and one inner layer of insulation (mineral wool) and plaster. The external surface is either rendered or with brick cladding and windows are double glazed. The flats differ in size, orientation and location within the four-storey building (Tables 2 and 3). All the flats are rated B in their SAP documents, with primary energy ranging from $76-85 \mathrm{kWh} / \mathrm{m}^{2}$ p.a. Figure 2 shows the plans with installed environmental logger locations (explained later) and location of the flats in the building.

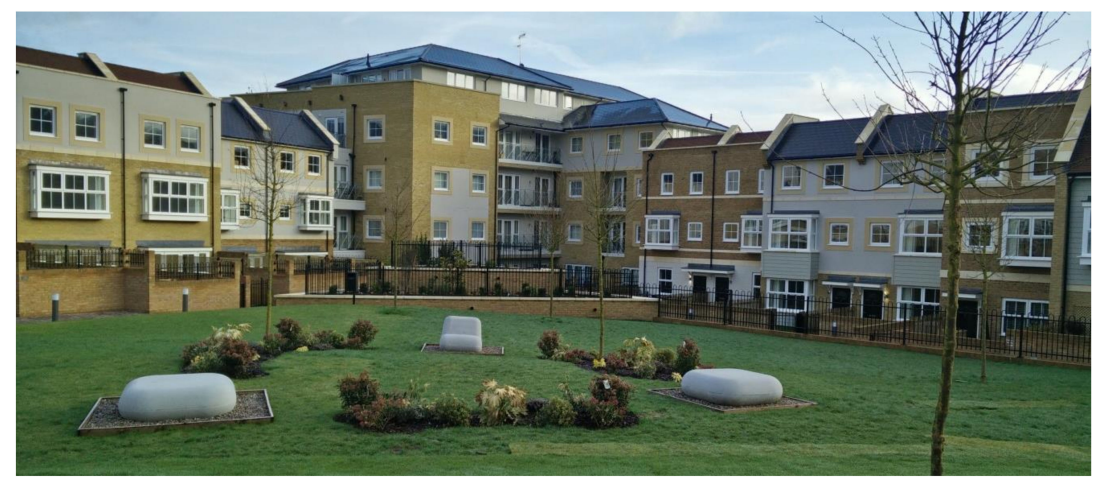

Figure 1. View of the housing development from the courtyard.
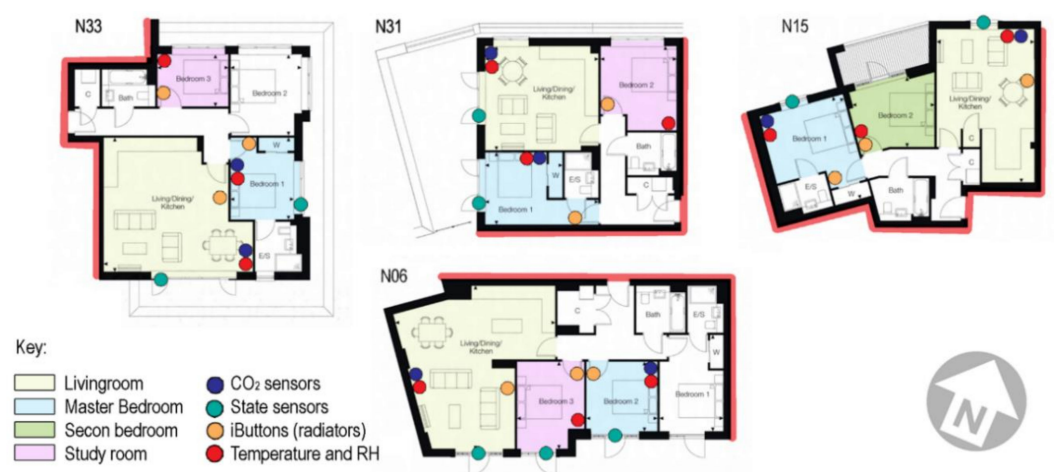

(a)

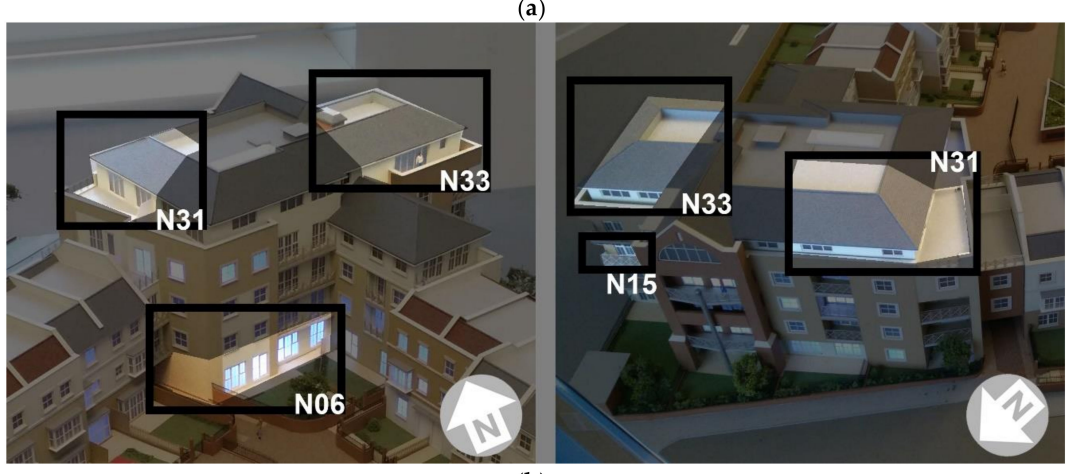

(b)

Figure 2. (a) Plans and data logger locations; (b) flat positions in building. 
Table 2. Case study physical characteristics (in order of increasing total floor area).

\begin{tabular}{cccccc}
\hline No. & $\begin{array}{c}\text { Total Floor Area } \\
\text { (TFA) }\left(\mathbf{m}^{\mathbf{2}}\right)\end{array}$ & $\begin{array}{c}\text { Ratio of Ext. } \\
\text { Surface Area to TFA }\end{array}$ & $\begin{array}{c}\text { Ratio of Windows } \\
\text { to TFA }\end{array}$ & $\begin{array}{c}\text { SAP Energy } \\
\text { Efficiency Rating }\end{array}$ & $\begin{array}{c}\text { Air Perm. } \\
\mathbf{( m}^{3} / \mathbf{h}_{\mathbf{m}} \mathbf{2} \text { @ } \mathbf{5 0} \text { Pa) }\end{array}$ \\
\hline N31 & 67 & 1.40 & 0.18 & $83(\mathrm{~B})$ & 4.64 \\
N15 & 72 & 0.39 & 0.10 & $84(\mathrm{~B})$ & 3.03 \\
N33 & 86 & 1.48 & 0.19 & $83(\mathrm{~B})$ & 3.95 \\
N06 & 95 & 1.43 & 0.15 & $84(\mathrm{~B})$ & 3.31 \\
\hline
\end{tabular}

Table 3. Case study occupancy details (in order of increasing total floor area).

\begin{tabular}{cclc}
\hline No. & Beds/Floor & \multicolumn{1}{c}{ Glazing Orientation } & $\begin{array}{c}\text { Occ. No. and Age } \\
\text { Range }\end{array}$ \\
\hline N31 & 2 bed/4th (top) & $\begin{array}{l}\text { Facing adjoining building roof: West-southwest } \\
\text { (WSW) (living room \& bedroom 1) }\end{array}$ & $1: 46-55$ \\
\hline N15 & 2 bed/2nd & Facing street Northwest (NW) (all rooms) & $\begin{array}{c}\text { 2 (often 3): } \\
16-25 \text { and 26-35 }\end{array}$ \\
\hline N33 & 3 bed/4th (top) & $\begin{array}{l}\text { Facing street: South-southeast (SSE) } \\
\text { (living room), East-northeast (ENE) (bedroom 1) }\end{array}$ & 1: over 65 \\
\hline N06 & 3 bed/ground & $\begin{array}{l}\text { Facing courtyard \& sheltered: South-southeast } \\
\text { (SSE) (all rooms) }\end{array}$ & 1: 56-65 \\
\hline
\end{tabular}

Data related to household characteristics and occupant behaviours were gathered through a review of design documentation and householder surveys. Table 4 lists the occupancy details for the flats. Most occupants spend more time at home than the typical working individual. At least one occupant of three flats work at home and the resident of the other flat (N33) is retired. The tenant in flat N31 had the most elaborate work/office arrangement, using many office/electric appliances (monitors, desktop computer, laptops, amplifiers etc.) and was at home most of the time during both weekdays and weekends. In flat N15 there were two tenants plus one guest staying regularly on weekends. The tenant of flat N33 spent most of the time at home, but mostly in the living room/kitchen in which he would cook and relax occasionally with visitors. The tenant of N06 lived alone but frequently had guests staying overnight (normally 1-3 days per week). With higher than average use, consistent with the living patterns outlined, the potential for occupants to experience increased periods of overheating is increased.

Table 4. Case study occupancy details.

\begin{tabular}{ccccl}
\hline No. & Living Room & Bedroom 1 & Bedroom 2 & \multicolumn{1}{c}{ Occupancy Details } \\
\hline N31 & $\begin{array}{c}8: 00-17: 00 \\
19: 00-21: 00\end{array}$ & Not measured & Not measured & $\begin{array}{l}\text { Works at home; away from } \\
\text { home 5-10\% of year: } \\
\text { modelled as away 2 h per day. }\end{array}$ \\
\hline N15 & $\begin{array}{c}8: 00-17: 00 \\
19: 00-21: 00\end{array}$ & 22:00-7:00 & 22:00-7:00 (freq. guest) & $\begin{array}{l}\text { 1 works at home 1-3 days per } \\
\text { week; away from home 5-10\% } \\
\text { of year: modelled as away 2 h } \\
\text { per day. }\end{array}$ \\
\hline N33 & $8: 00-21: 00$ & 22:00-7:00 & Not measured & $\begin{array}{l}\text { Most of the time at home; goes } \\
\text { to gym on Wednesdays }\end{array}$ \\
\hline N06 & $12: 00-21: 00$ & 22:00-7:00 & 22:00-7:00 (freq. guest) & $\begin{array}{l}\text { Works at home/out mornings } \\
\text { and evenings on weekends }\end{array}$ \\
\hline
\end{tabular}

\section{Local Climate}

The location in southeast (SE) England has summer average temperature between $18-16{ }^{\circ} \mathrm{C}$. The temperature graphs in Figure 3, known as Nicol graphs, show a calculated comfort temperature 
based on the theory that the temperature which people find comfortable indoors varies with the mean outdoor temperature. This comfort temperature applies to summer conditions in freely running buildings (not air-conditioned ones) but it otherwise gives a general idea of the comfort conditions required by the building occupants who have adapted to the local climate. According to the Nicol graphs, the free-running temperature tolerance for the summer ranges from $19-21^{\circ} \mathrm{C}$. Based on maximum temperatures in the summer of 2017 this adaptive comfort temperature may stretch up to $23.6^{\circ} \mathrm{C}$.

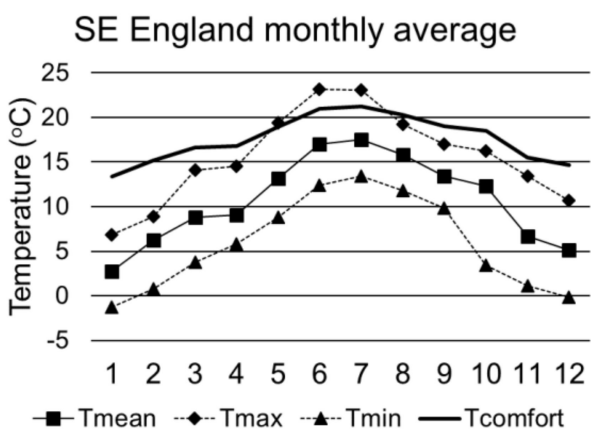

(a)

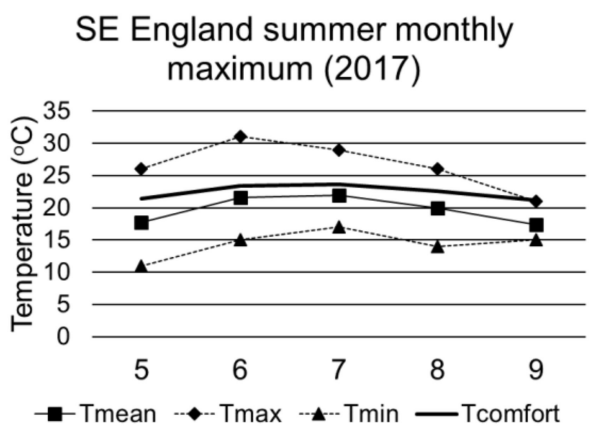

(b)

Figure 3. (a) Monthly average temperature for case study location; (b) Summer (2017) monthly maximum temperatures for case study location.

\subsection{Methods}

In-situ monitoring of the indoor environment (air temperature, $\mathrm{RH}$, and $\mathrm{CO}_{2}$ levels at five-minute intervals) was carried out in the four flats using Hobo and Tinytag data logger, for one month from 26 June 2017-26 July 2017 as representative of the summer season. The following parameters were monitored as follows:

- Indoor air temperature and relative humidity (RH) (every $5 \mathrm{~min}$ ),

- Outdoor air temperature and RH (every $5 \mathrm{~min}$ ),

- $\mathrm{CO}_{2}$ levels (every $5 \mathrm{~min}$ ),

- Window opening (every change of state as proportion of opening/closed).

Data loggers were placed in the rooms listed in Table 4, while Figure 2 shows the plans and data logger locations. Environmental monitoring was performed in all living rooms, and most bedrooms. Unfortunately, the temperature data were defective in N31 bedrooms and N33 bedroom 3 . Figure 4 shows example images of the loggers installed. The technical specifications of the devices used in the monitoring study are reported in Table 5. Statistical analysis was carried out using SPSS software package to produce descriptive statistics for the monitoring data.
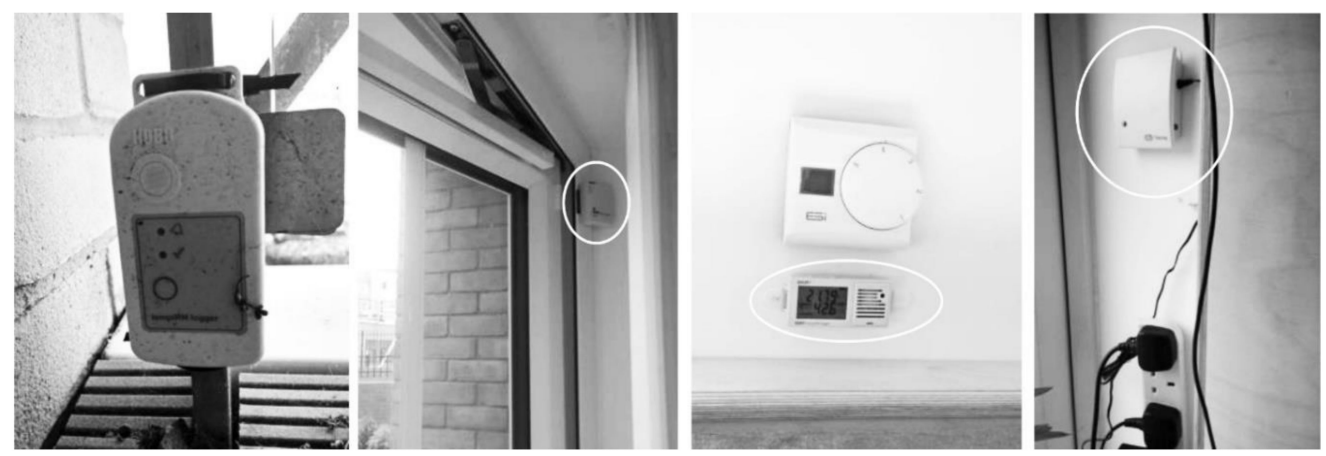

Figure 4. Environmental monitoring devices installed in the flats. From left: Outdoor temperature and $\mathrm{RH}$ logger, window state logger, interior temperature and $\mathrm{RH}$ logger and $\mathrm{CO}_{2}$ loggers. 
Table 5. Specification of data loggers used in the monitoring study.

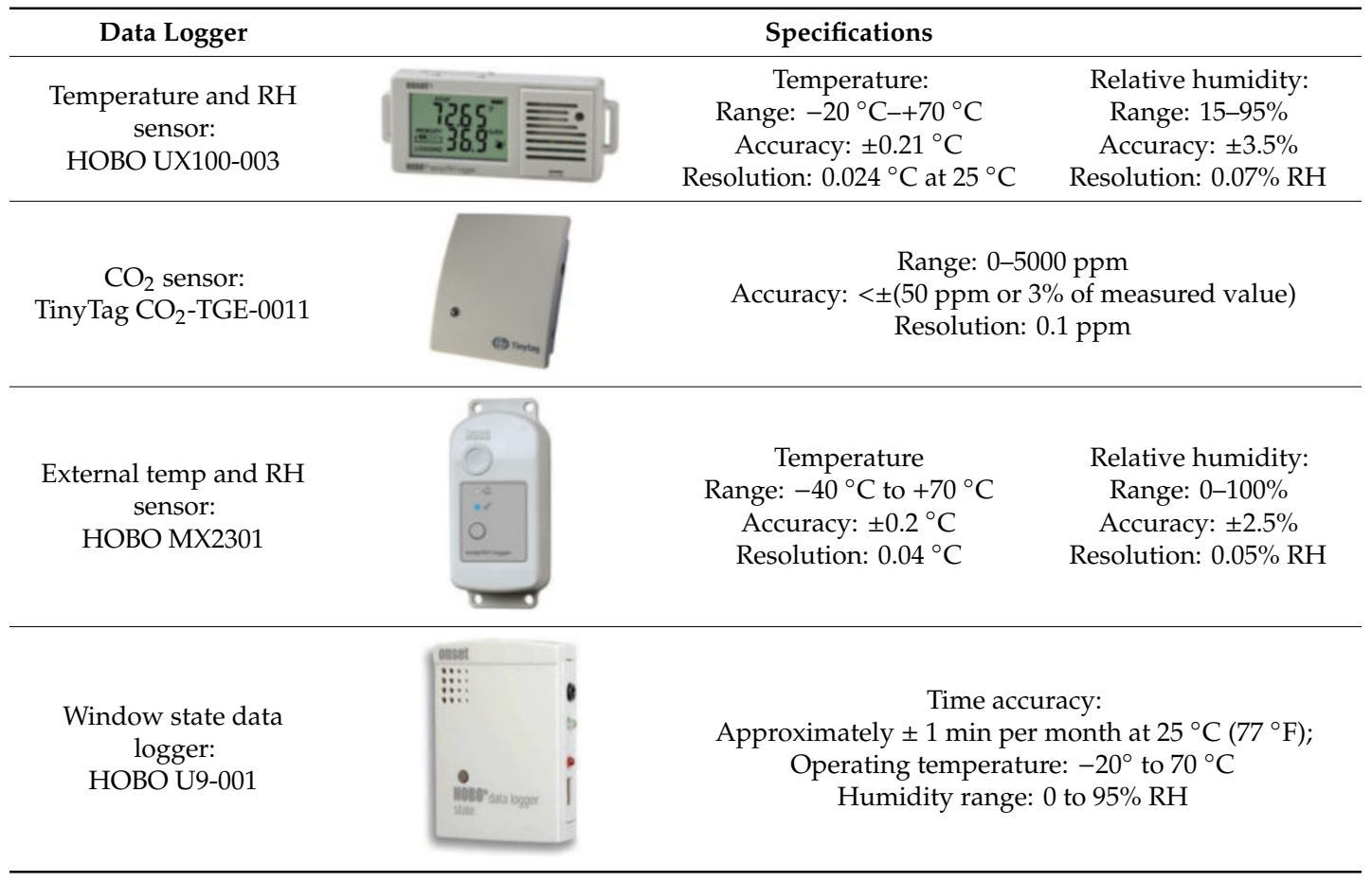

A questionnaire survey was carried out at the beginning of the pilot study to gather general information regarding households' characteristics and occupancy patterns over weekdays and weekends, including use of heating control, hot water, laundry and drying habits. To gather data on occupant perception, the Building Use Studies (BUS) questionnaire [50], an established methodology of evaluation of occupant satisfaction, was carried out after one year of monitoring in May 2018 covering an entire year (summer 2017-Winter 2018). The purpose of the questionnaire was to gather retrospective feedback from residents on various aspects of building performance, including thermal comfort (in summer and winter) and ventilation, lighting and noise, personal control, and design. BUS uses long range memory of respondents and provides a glimpse into the resident's overall summer experience. The BUS results are also used for benchmarking the building against a reference building set from the large BUS Methodology database. This study presents the variables relevant to summer environmental comfort in the case study flats. Figure 5 shows an example of questions included in the BUS questionnaire.

Temperature in summer Please tick your rating on each scale

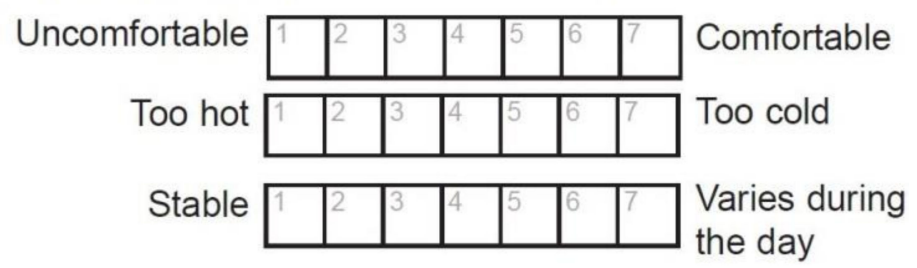

Figure 5. BUS question sample.

To assess the impact of window opening behaviour, a window opening ratio (WOR) was calculated by multiplying the percentage of openness (from $0-100 \%$ ) by the number of seconds the window is open for every hour.

$$
W O R=\left(\Sigma(a \times b)_{i}\right) / n
$$

where: 
Percentage of openness $=a(100 \%$ open $=1.0)$ and

Proportion of each hour the window is open $=b(3600 \mathrm{~s} / \mathrm{h}=1.0)$.

\subsection{Overheating Assessment}

As noted above in the literature review, the static and dynamic (adaptive) methods were used to assess the risk of summertime overheating in the dwellings. The greatest occupancy potential was used for the analysis in these models; i.e., a single pattern is applied to everyday, for example, though N15 works from home only 1-3 days per week, the days that the occupant works from home are used in the model to capture the worst-case potential.

For static overheating criteria in non-air-conditioned dwellings, CIBSE's Environmental Design Guide A $[28,39]$ recommends that values for indoor comfort temperatures should be $25^{\circ} \mathrm{C}$ for living areas and $23^{\circ} \mathrm{C}$ for bedrooms. CIBSE notes that temperatures are expected to be lower at night with people finding that sleeping in warm conditions is difficult, particularly above $24^{\circ} \mathrm{C}$. Environmental Design Guide A provides these static benchmark summer peak temperatures and overheating criteria:

- $1 \%$ of annual occupied hours over $28^{\circ} \mathrm{C}$ in living rooms

- $1 \%$ of annual occupied hours over $26^{\circ} \mathrm{C}$ in bedrooms

Alternatively, dynamic/adaptive overheating criteria were developed taking the outdoor conditions and human adaptation into account by identifying comfort limits based on a running mean of external temperature and the quality of the thermal comfort required. Based on this, the CIBSE TM52 [29] document provides a series of criteria by which the risk of overheating can be assessed. These are:

- Criterion 1: hours of exceedance-limit for the number of hours that the operative temperature can exceed the threshold comfort temperature

- Criterion 2: daily weighted exceedance-severity of overheating within any one day

- Criterion 3: upper limit temperature-temperatures which exceed the absolute maximum temperature are unacceptable

For Category II, normal expectation for new buildings and renovations, the first criterion recommends that the number of hours during which the internal temperatures are $1 \mathrm{~K}$ higher or equal to the upper comfort limit during the period from May to September should not exceed 3\% of occupied hours. The calculations for the criteria will not be repeated here as they are well documented in several references provided below, e.g., [21] as well as in the original document [29].

As is common in many domestic monitoring studies, indoor air temperature is monitored in the study are rather than operative temperature (used in overheating criteria). However, Lomas and Porritt [51] suggest that commonly used sensors (such as those used in this study) are likely to record a mix of air and radiant temperatures, making them closer to temperatures experienced by occupants.

\section{Results}

\subsection{Indoor Temperature}

Indoor temperatures across the four flats in the monitored period (June to July 2017) were found to be warmer than outdoors in summer. As can be seen in Figure 6, indoor temperatures were more stable in N15 and N06 and more variable in N31 and N33, both of which are top-floor flats. Table 6 provides summary characteristics for the flats.

The mean indoor temperatures ranged from $27^{\circ} \mathrm{C}$ in N31 to $24^{\circ} \mathrm{C}$ in N06, while the outdoor mean temperature was $19^{\circ} \mathrm{C}$. Table 7 shows the descriptive statistics for outdoor and indoor temperatures for living room and bedrooms of the four flats inclusive of all hours. The flats with the higher standard deviation in temperature are the top floor flats (N31 and N33). Incidentally these flats also have a combination of larger exposed surface area (SA) to total floor area (FA) ratio i.e., SA/FA. These two flats also have dominant west or south facing glazing with the largest ratios of glazing $(\mathrm{G})$ to floor area (FA) 
i.e., GA/FA ratio. The highest deviation is in Flat N31. N31 differs most from N33 regarding window orientation (WSW); therefore, in this flat, the solar gains are, in theory, leading to greater standard deviation in temperature. As described in more detail later, window opening behaviour is not enough to explain this deviation either.

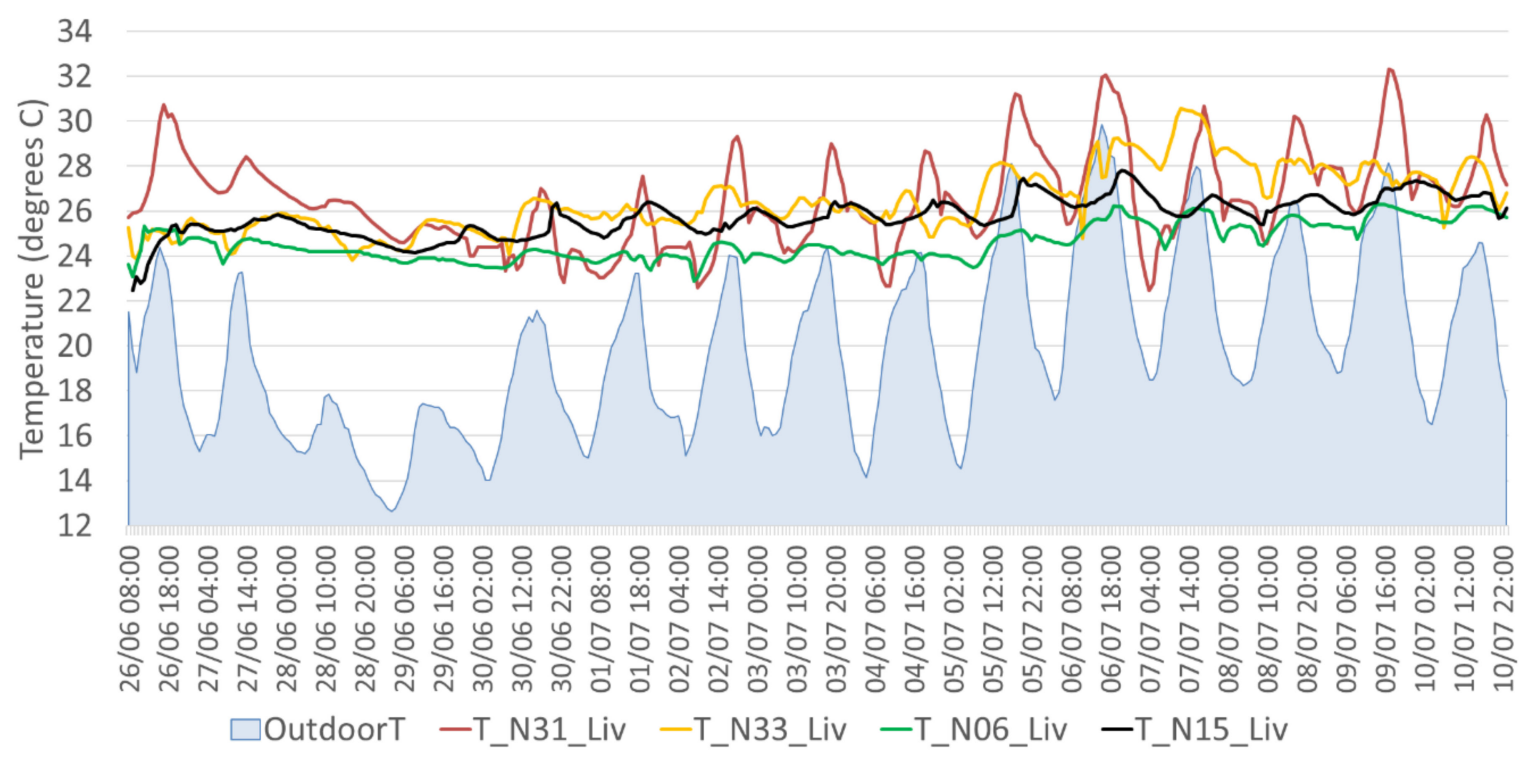

Figure 6. Living room temperatures during period of maximums (26 June-10 July 2017).

Table 6. Summary characteristics of flats and monitored rooms.

\begin{tabular}{|c|c|c|c|c|c|c|c|}
\hline No. & $\begin{array}{l}\text { Floor } \\
\text { Level }\end{array}$ & Exposure & TFA $\left(m^{2}\right)$ & $\begin{array}{l}\text { Ratio of Ext. } \\
\text { Surface Area to } \\
\text { TFA (SA/FA) }\end{array}$ & $\begin{array}{c}\text { Ratio of } \\
\text { Windows to } \\
\text { TFA (GA/FA) }\end{array}$ & $\begin{array}{c}\text { Glazing } \\
\text { Orientation }\end{array}$ & WOR \\
\hline N31 & $\begin{array}{l}\text { Top } \\
\text { floor }\end{array}$ & $\begin{array}{c}\text { High/nearby roof } \\
\text { exposure }\end{array}$ & 67 & 1.40 & 0.18 & $\begin{array}{l}\text { Living room } \\
\text { WSW }\end{array}$ & 0.19 \\
\hline \multirow{2}{*}{ N33 } & \multirow{2}{*}{$\begin{array}{l}\text { Top } \\
\text { floor }\end{array}$} & \multirow{2}{*}{ Normal/street view } & \multirow{2}{*}{86} & \multirow{2}{*}{1.48 (largest) } & \multirow{2}{*}{0.19 (largest) } & Living room SSE & 0.005 \\
\hline & & & & & & Bedroom 1 ENE & 0.02 \\
\hline \multirow{3}{*}{ N15 } & \multirow{3}{*}{$\begin{array}{l}\text { 2nd } \\
\text { floor }\end{array}$} & \multirow{3}{*}{ Normal/street view } & \multirow{3}{*}{72} & \multirow{3}{*}{0.39} & \multirow{3}{*}{0.10} & Living room $\mathrm{NW}$ & 0.30 \\
\hline & & & & & & Bedroom $1 \mathrm{NW}$ & - \\
\hline & & & & & & Bedroom $2 \mathrm{NW}$ & - \\
\hline \multirow{3}{*}{ N06 } & \multirow{3}{*}{$\begin{array}{l}\text { Ground } \\
\text { floor }\end{array}$} & \multirow{3}{*}{$\begin{array}{l}\text { Courtyard/sheltered } \\
\text { by building on east } \\
\text { side }\end{array}$} & \multirow{3}{*}{95 (largest) } & \multirow{3}{*}{1.43} & \multirow{3}{*}{0.15} & Living room SSE & 0.11 \\
\hline & & & & & & Bedroom 1 SSE & 0.18 \\
\hline & & & & & & Bedroom 2 SSE & - \\
\hline
\end{tabular}

Table 7. Descriptive statistics for outdoor and indoor temperature measurement for all rooms, for all hours of the monitored period.

\begin{tabular}{|c|c|c|c|c|c|c|c|c|c|c|}
\hline & \multirow[b]{2}{*}{ Outdoor } & \multicolumn{4}{|c|}{ Living Rooms } & \multicolumn{5}{|c|}{ Bedrooms } \\
\hline & & N31 & N33 & N06 & N15 & $\begin{array}{c}\text { N33 } \\
\text { B-1 }\end{array}$ & $\begin{array}{c}\text { N06 } \\
\text { B-1 }\end{array}$ & $\begin{array}{c}\text { N06 } \\
\text { B-2 }\end{array}$ & $\begin{array}{c}\text { N15 } \\
\text { B-1 }\end{array}$ & $\begin{array}{l}\text { N15 } \\
\text { B-2 }\end{array}$ \\
\hline Mean & $19^{\circ} \mathrm{C}$ & $27^{\circ} \mathrm{C}$ & $26^{\circ} \mathrm{C}$ & $24^{\circ} \mathrm{C}$ & $26^{\circ} \mathrm{C}$ & $26^{\circ} \mathrm{C}$ & $24^{\circ} \mathrm{C}$ & $24^{\circ} \mathrm{C}$ & $25^{\circ} \mathrm{C}$ & $25^{\circ} \mathrm{C}$ \\
\hline $\operatorname{Max}$ & $30^{\circ} \mathrm{C}$ & $33^{\circ} \mathrm{C}$ & $31^{\circ} \mathrm{C}$ & $28^{\circ} \mathrm{C}$ & $28^{\circ} \mathrm{C}$ & $30^{\circ} \mathrm{C}$ & $27^{\circ} \mathrm{C}$ & $27^{\circ} \mathrm{C}$ & $28^{\circ} \mathrm{C}$ & $28^{\circ} \mathrm{C}$ \\
\hline Min & $10^{\circ} \mathrm{C}$ & $22^{\circ} \mathrm{C}$ & $23^{\circ} \mathrm{C}$ & $20^{\circ} \mathrm{C}$ & $22^{\circ} \mathrm{C}$ & $21^{\circ} \mathrm{C}$ & $21^{\circ} \mathrm{C}$ & $22{ }^{\circ} \mathrm{C}$ & $21^{\circ} \mathrm{C}$ & $20^{\circ} \mathrm{C}$ \\
\hline Std. Dev. & $3.5^{\circ} \mathrm{C}$ & $2.1^{\circ} \mathrm{C}$ & $1.2^{\circ} \mathrm{C}$ & $0.9^{\circ} \mathrm{C}$ & $0.8^{\circ} \mathrm{C}$ & $1.4^{\circ} \mathrm{C}$ & $0.9^{\circ} \mathrm{C}$ & $0.9^{\circ} \mathrm{C}$ & $0.9^{\circ} \mathrm{C}$ & $0.8^{\circ} \mathrm{C}$ \\
\hline
\end{tabular}


Figure 7 shows the indoor temperature distribution in the measured rooms. The 'overheating thresholds' and recommended temperatures are provided in CIBSE Guide A [28] and relate to the static overheating method. As with the standard deviation in temperature, the top floor flats are also exhibiting longer ranges above the upper quartile and more outliers above this. The same physical characteristics are influential here as with standard deviation in temperature. Flat N06 is consistently lower in indoor temperature than the other flats, despite having the largest floor area, as well as large SA/FA and GA/FA ratios. However, N06 is located on the ground floor and is notably sheltered by a courtyard which appears to be influencing indoor temperatures. Figure 8 shows N06 flat in morning shade. It is worth noting here that the resident of N06 considered the flat to be lacking 'enough' natural light.

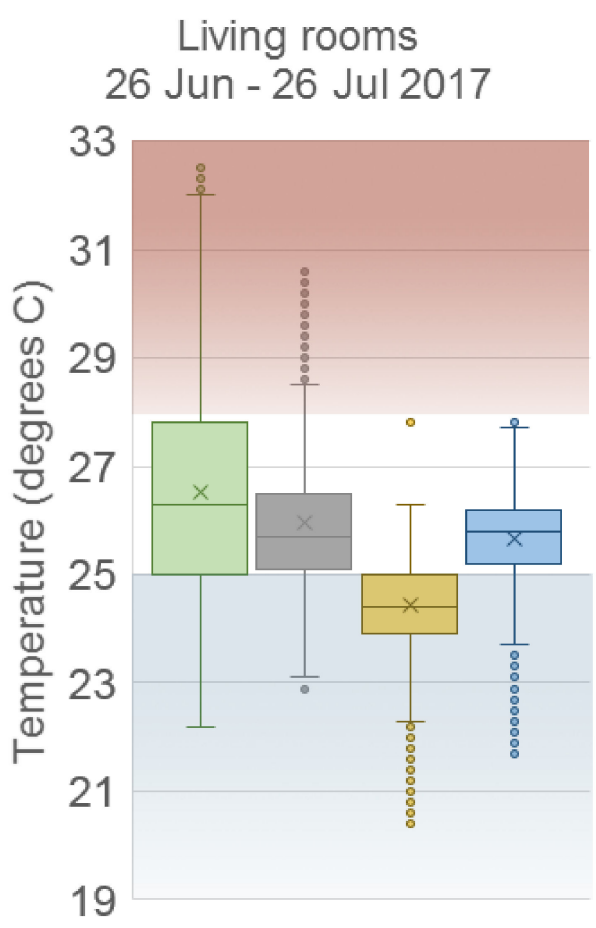

$\square$ N31 $\square$ N33 $\square$ N06 $\square$ N15

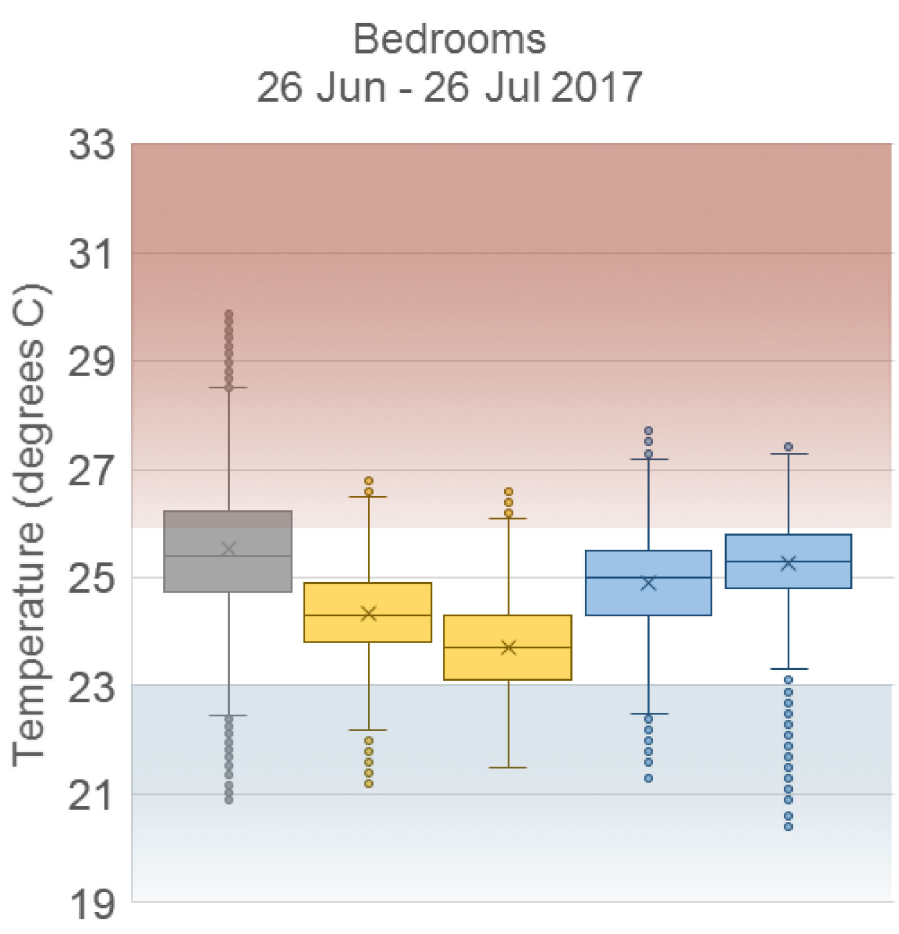

$\square$ N33 $\square$ N06 b-1 $\square$ N06 b-2 $\square$ N15 b-1 $\square$ N15 b-2

Overheating threshold ( $>26$ bedrooms / $>28$ living rooms)

Recommended comfort temperatures ( 23 bedrooms / 25 living rooms)

Figure 7. Indoor temperature distribution across all measured rooms in the flats.

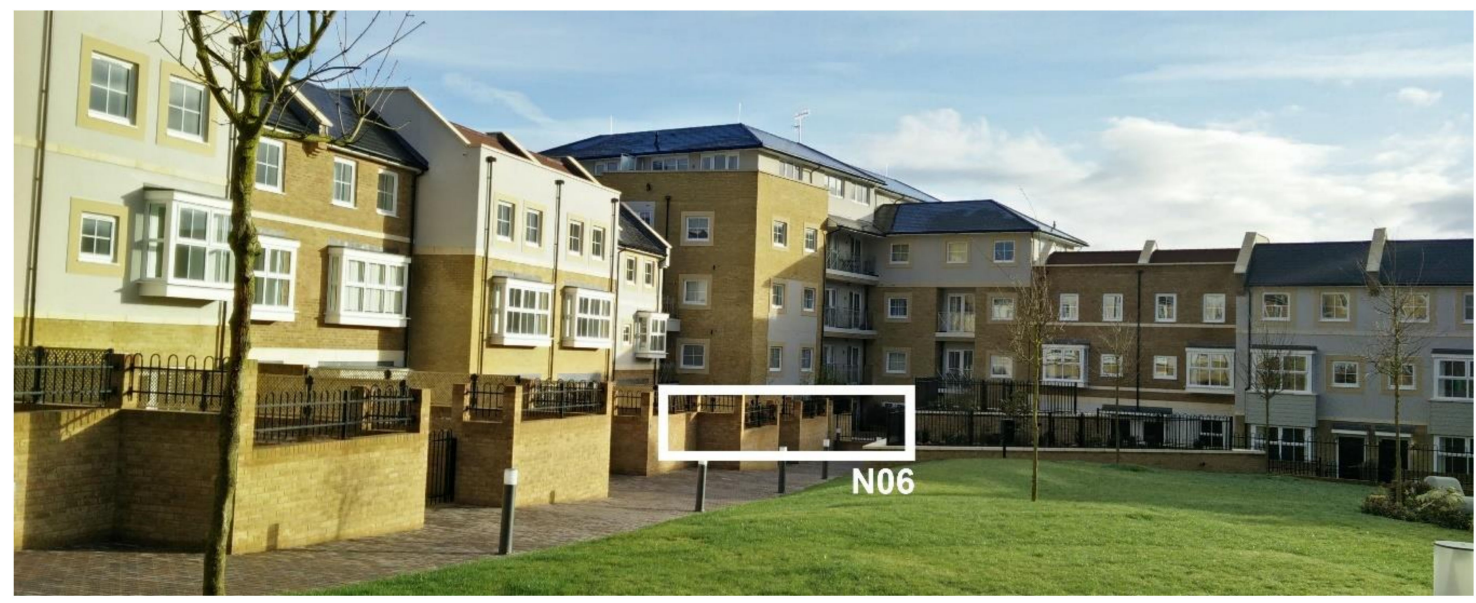

Figure 8. N06 highlighted in morning sun; extent of shading from building. 
Figure 9 shows the correlation between indoor temperature and SA/FA ratio and GA/FA ratio. The $y$-axis shows the mean number of hours across all rooms monitored in the flat that are above $26^{\circ} \mathrm{C}$. The significance of $26^{\circ} \mathrm{C}$ is that it is the minimum threshold at which overheating is defined using the static method. It is important to remember that SA/FA and GA/FA do not consider orientation or exposure, e.g., how N06 is sheltered from solar gains. Nonetheless, it is theorized that the impact of (lack of) solar gains are skewing the correlations in the left graph. The right graph shows the correlations with N06 removed. SA/FA goes from negligible to very strong and GA/FA from moderately weak to very strong. To summarise the impact of SA/FA and GA/FA, as either one is increased, there is a distinct increase in the number of hours over $26^{\circ} \mathrm{C}$.

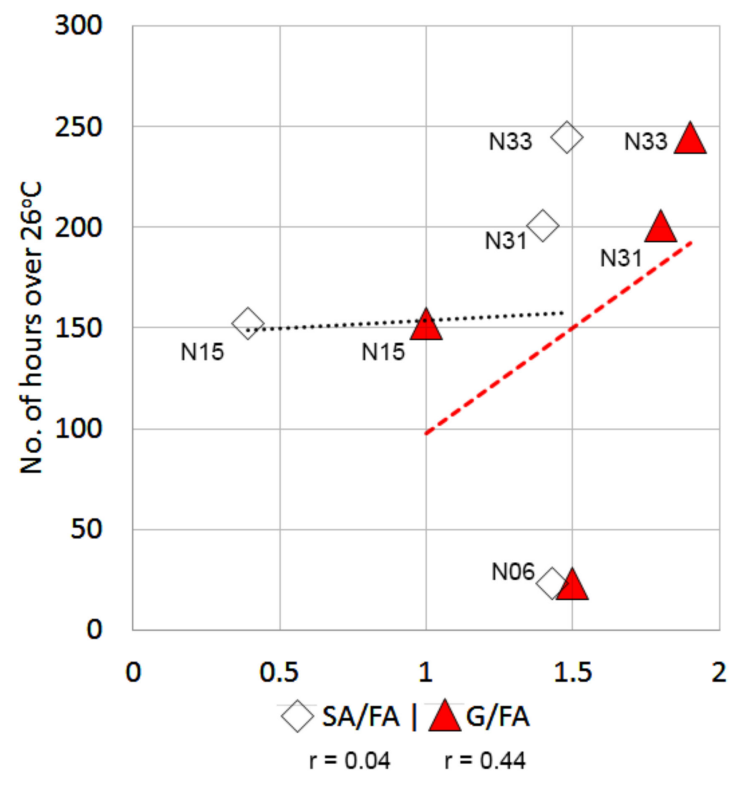

(a)

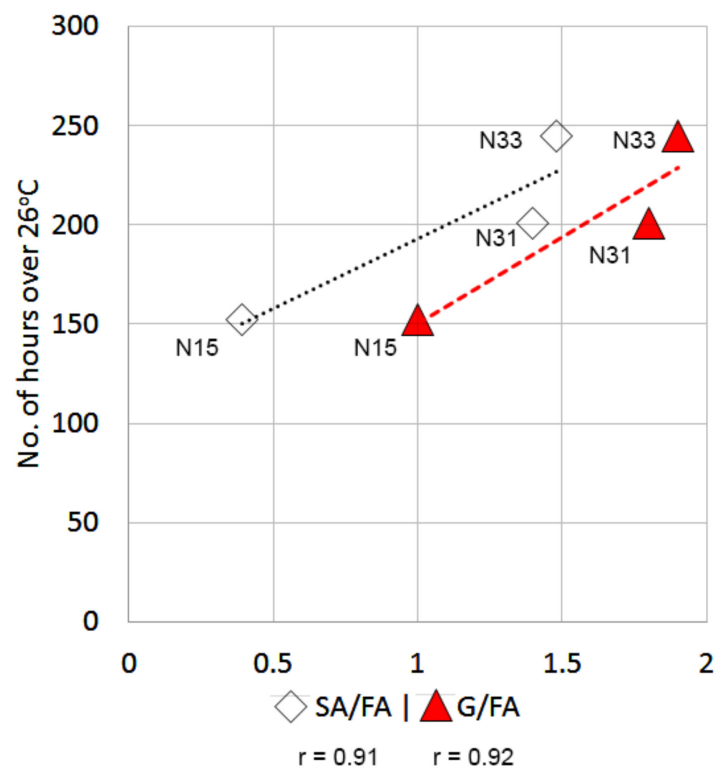

(b)

Figure 9. High temperature hours vs. surface area to floor area ratio (SA/FA) and glazing to floor area ratio (GA/FA): (a) Flats N31, N33, N15, N06; (b) Flats N31, N33, N15.

The maximum temperature in the WSW exposed top-floor flat, N31, reached up to $33{ }^{\circ} \mathrm{C}$, more than the maximum outdoor temperature recorded over the same period $\left(30.3^{\circ} \mathrm{C}\right)$, while in $\mathrm{N} 33$ (SSE exposure), indoor temperature reached up to $30.7^{\circ} \mathrm{C}$. Figure 10 investigates the correlation between estimated solar gain and indoor temperature. The $x$-axis shows a ratio of solar radiation $\left(\mathrm{kWh} / \mathrm{m}^{2} /\right.$ day) on a $90^{\circ}$ surface per area of glazing $\left(\mathrm{m}^{2}\right)$. For solar radiation, the value for the month of July was used to represent summer conditions at each respective window's orientation. The $y$-axis shows the mean number of hours across all rooms monitored in each flat that are above $26^{\circ} \mathrm{C}$. The graph on the left shows that there is strong correlation considering the four flats. N06, located on the ground floor, demonstrates little to no overheating. N06 has south facing glazing which is easier to shade with balcony overhangs; however, in the case of N06, the flat is also facing a garden courtyard and is in a corner of the building where the building is shading the glazing for much of the morning and late afternoon. The graph on the right of Figure 10 shows N06 excluded given the unknown impact of the sheltered condition. Doing so, increased the strength of the correlation between incident solar radiation in more exposed flats and temperature above $26^{\circ} \mathrm{C}$. 


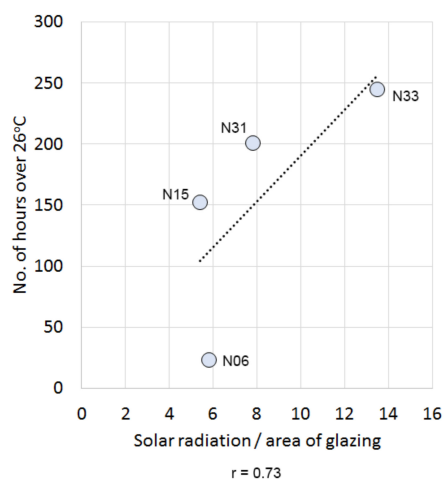

(a)

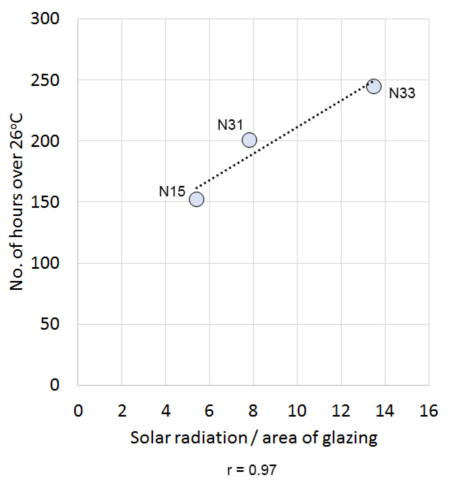

(b)

Figure 10. High temperature hours vs. solar radiation per area of glazing: (a) Flats N31, N33, N15, N06; (b) Flats N31, N33, N15.

\subsection{Overheating Assessment}

The indoor temperature measurements in summer revealed the prevalence of overheating across most of the flats, especially in the top floor flats. Table 8 shows overheating results for all monitored rooms in the flats. The only room to show severity of temperature using the adaptive method was the living room of N31; however, according to this method no room overheated as at least two criteria must fail to be classed as overheated [29]. The overheating results for 'all hours' align with the ranking of flats in the correlation analyses above and maximum temperature results, i.e., N31 also had the greatest maximum temperature reading. Bedrooms generally tend to overheat more than living rooms; however, it is important to remember that the overheating thresholds are different in these two room types. In terms of temperature absolutes, living rooms are consistently warmer for longer than their respective bedroom counterparts, i.e., if an occupant were to attempt to sleep in their living room, they would experience the same discomfort (perhaps more). Figure 11 shows the temperature ranges in the living rooms and bedrooms. The difference between temperature absolutes and magnitude of static overheating can be seen here. As an example, if the N15 living room was measured with the same threshold as the bedrooms, the living room would also be overheated. Overall, the bedrooms show a much larger period where temperatures remained between the recommended temperature $\left(23^{\circ} \mathrm{C}\right)$ and overheating $\left(26^{\circ} \mathrm{C}\right)[39]$.

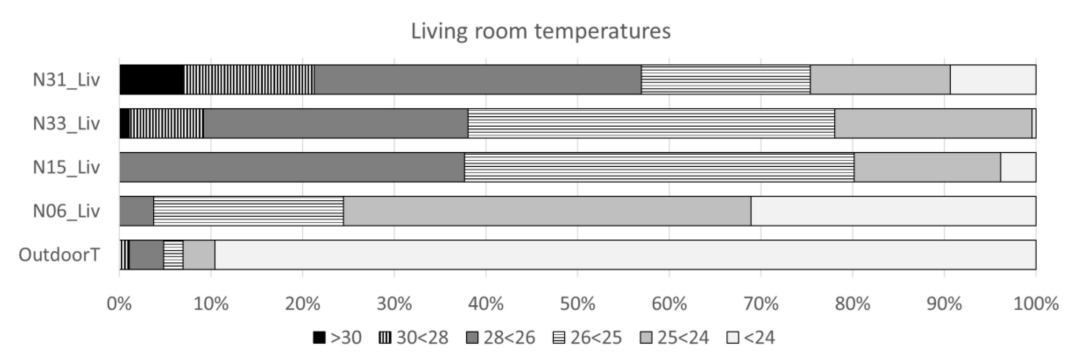

(a)

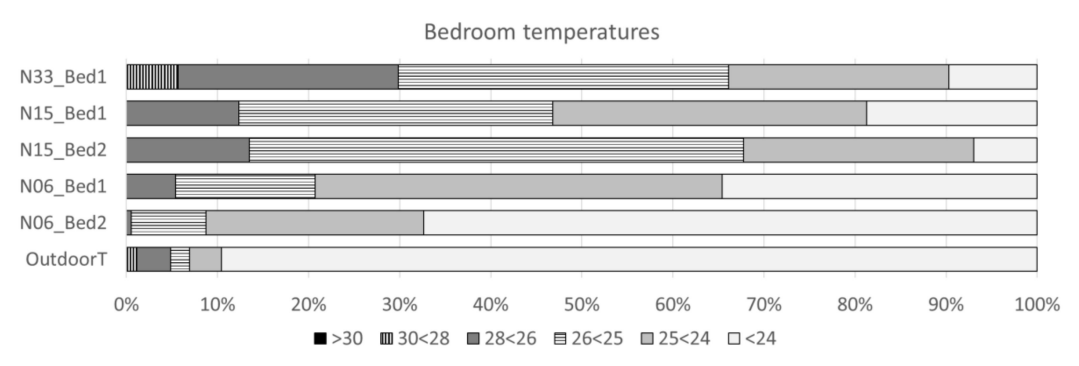

(b)

Figure 11. Temperature ranges in living rooms (a) and bedrooms (b). 
Table 8. Overheating results $(\mathrm{OH}=$ overheating $)$.

\begin{tabular}{cccccc}
\hline No. & Room & $\begin{array}{c}\text { Window } \\
\text { Orientation/Floor }\end{array}$ & $\begin{array}{c}\text { Static Method } \\
\text { (Occupied Hours) }\end{array}$ & $\begin{array}{c}\text { Static Method } \\
\text { (All Hours) }\end{array}$ & $\begin{array}{c}\text { Adaptive Method } \\
\text { (Criteria Failed) }\end{array}$ \\
\hline N31 & Living room & $\begin{array}{c}\text { West-southwest/4th } \\
\text { floor }\end{array}$ & $34 \%-\mathrm{OH}$ & $21 \%-\mathrm{OH}$ & Criterion 2 \\
\hline N33 & Living room & $\begin{array}{c}\text { South-southeast/4th } \\
\text { floor }\end{array}$ & $11 \%-\mathrm{OH}$ & $9 \%-\mathrm{OH}$ & - \\
\cline { 2 - 6 } & Bedroom 1 & $\begin{array}{c}\text { East-northeast/4th } \\
\text { floor }\end{array}$ & $33 \%-\mathrm{OH}$ & $30 \%-\mathrm{OH}$ & - \\
\hline \multirow{2}{*}{ N15 } & Living room & $\begin{array}{c}\text { Northwest/2nd } \\
\text { floor }\end{array}$ & $0 \%$ & $0 \%$ & - \\
\cline { 2 - 6 } & Bedroom 1 & $\begin{array}{c}\text { Northwest/2nd } \\
\text { floor }\end{array}$ & $16 \%-\mathrm{OH}$ & $12 \%-\mathrm{OH}$ & - \\
\hline \multirow{2}{*}{ Bedroom 2 } & $\begin{array}{c}\text { Northwest/2nd } \\
\text { floor }\end{array}$ & $23 \%-\mathrm{OH}$ & $14 \%-\mathrm{OH}$ & - \\
\cline { 2 - 6 } & Living room & $\begin{array}{c}\text { South-southeast/gr. } \\
\text { floor }\end{array}$ & $0 \%$ & $0 \%$ & - \\
\cline { 2 - 6 } & Bedroom 1 & $\begin{array}{c}\text { South-southeast/gr. } \\
\text { floor }\end{array}$ & $0 \%$ & $\mathbf{5} \%-\mathrm{OH}$ & - \\
\hline
\end{tabular}

\subsection{Window Opening and Indoor Temperature}

Window opening appeared to have some influence, if minimal overall, on the internal temperatures of the flats. Table 9 shows the mean and maximum temperature difference between interior and exterior when windows in the case study flats were open and closed. As concluded in the analysis above, it is likely that a combination of vertical location of the flat, SA/FA ratio, GA/FA ratio and orientation seemed to have a notable impact on the indoor temperature (temperature maximums) than when windows were left open or closed. The contrast is best seen with the north facing N15 living room window opening where the window is open $76 \%$ of the measured time and there is little difference in temperature whether the windows are open or closed.

Table 9. Difference in interior and exterior temperature data from window opening $(\mathrm{O}=$ open, $\mathrm{C}=$ closed).

\begin{tabular}{|c|c|c|c|c|c|c|c|c|c|c|}
\hline \multirow{3}{*}{$\begin{array}{l}\text { Window Opening } \\
\text { Ratio (WOR) } \\
\text { (\% of Time) }\end{array}$} & \multicolumn{2}{|c|}{$\begin{array}{l}\text { N31 Living } \\
\text { Room }\end{array}$} & \multicolumn{2}{|c|}{$\begin{array}{l}\text { N33 Living } \\
\text { Room }\end{array}$} & \multicolumn{2}{|c|}{ N33 Bedroom 1} & \multicolumn{2}{|c|}{$\begin{array}{l}\text { N15 Living } \\
\text { Room }\end{array}$} & \multicolumn{2}{|c|}{$\begin{array}{l}\text { N06 Living } \\
\text { Room }\end{array}$} \\
\hline & \multicolumn{2}{|c|}{$0.19(29 \%)$} & \multicolumn{2}{|c|}{$0.005(2 \%)$} & \multicolumn{2}{|c|}{$0.02(5 \%)$} & \multicolumn{2}{|c|}{$0.30(76 \%)$} & \multicolumn{2}{|c|}{$0.11(30 \%)$} \\
\hline & O & $\mathrm{C}$ & $\mathrm{O}$ & C & O & C & O & $\mathrm{C}$ & O & $\mathrm{C}$ \\
\hline Mean $\left({ }^{\circ} \mathrm{C}\right)^{1}$ & 4.1 & 7.2 & 5.9 & 6.9 & 2.6 & 6.5 & 6.0 & 6.7 & 3.0 & 5.6 \\
\hline $\operatorname{Max}\left({ }^{\circ} \mathrm{C}\right)^{1}$ & 9.5 & 12.3 & 9.0 & 14.4 & 5.2 & 14.7 & 13.8 & 12.1 & 8.9 & 14.0 \\
\hline $\begin{array}{l}\text { Hours over OH } \\
\text { threshold (\% of total } \\
\text { over threshold) }\end{array}$ & $\begin{array}{c}16 \\
(20 \%)\end{array}$ & $\begin{array}{c}66 \\
(80 \%)\end{array}$ & 0 & $\begin{array}{c}69 \\
(100 \%)\end{array}$ & $9(4 \%)$ & $\begin{array}{c}36 \\
(96 \%)\end{array}$ & 0 & 0 & 0 & 0 \\
\hline
\end{tabular}

${ }^{1}$ Mean and maximum difference in temperature between interior and exterior for the entire set of data whilst windows are either open or closed.

Another reason why orientation may have more influence than window opening in these flats, is that though the windows were used far more in N31 vs. N33, the correlation (r) between external and internal temperature were the same (N31: $r=0.59$; N33: $r=0.60)$. The window opening ratio (WOR) in N15 was much higher at 0.30 but the external and internal temperature correlation is lower: $r=0.37$. It was expected that, where the windows are open $76 \%$ of the time (N15), the relationship between interior and exterior temperature would be stronger. Additionally, the standard deviation in 
temperature should be higher. This difference tends to confirm that temperature regulation in the flats was more affected by solar gains through orientation and GA/FA ratio combined with heat retention in well-insulated fabric and flat location, than ventilation as afforded to these flats.

Figure 12 shows the flats' living room temperature and WOR analysis during a period with the peak external temperatures and resultant peak indoor temperatures for all flats (5-10 July). Flat N06 window opening appears to have a slight effect on indoor temperatures, but the overall ongoing trend is lower and not a result of ventilation. Flat N31 is also at times able to cool the space by opening windows in the morning but as the exterior temperature increases during June-July, ventilation on its own, is unable to offset the temperature rise due to significant afternoon solar gains. Flat N15 shows the effect of long-term window opening with a slight downward trend in temperature with a slight lag in daytime temperature increase. Overall, the greater fluctuation in temperature in N31 is theorised to be mostly attributed to solar gains and the upper level exposure of the flat.

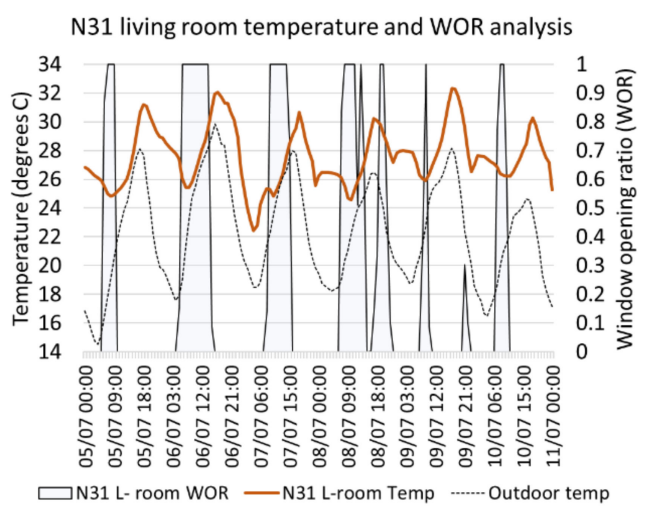

(a)

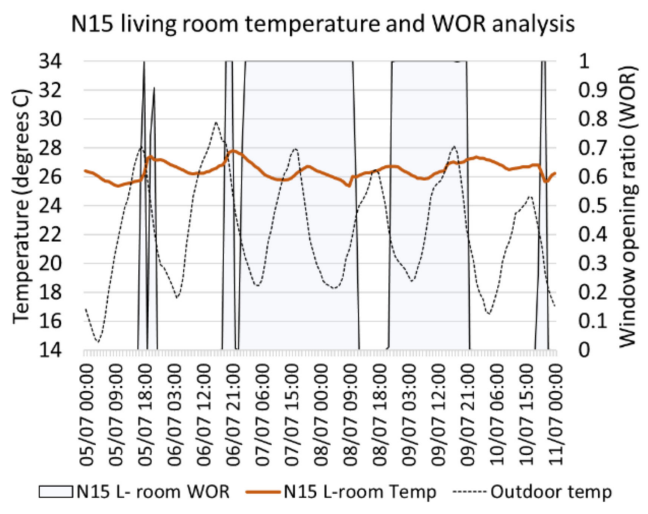

(c)

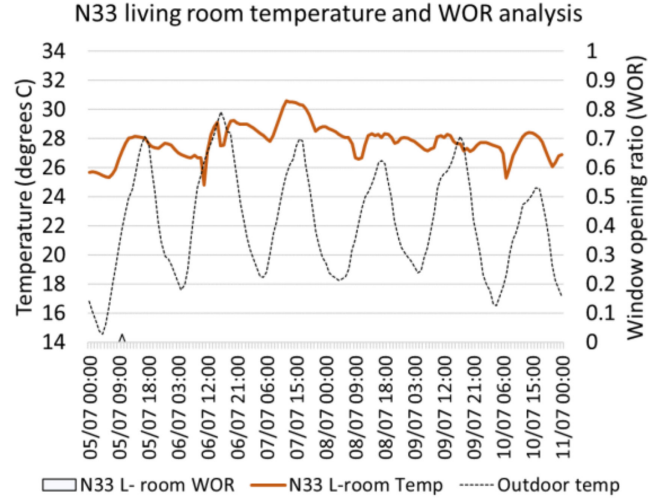

(b)

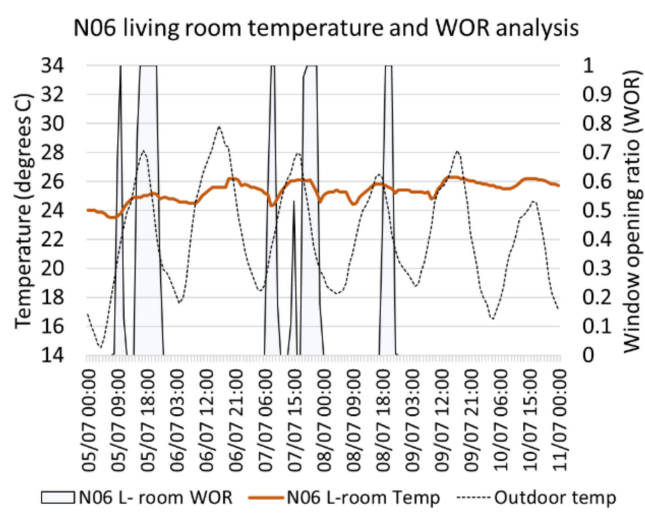

(d)

Figure 12. Living room temperature in the case study flats and window opening ratio: (a) Flat N31; (b) Flat N33; (c) Flat N15; (d) Flat N06.

Figure 13 shows the same temperature correlation as above but against WOR in respective rooms. In the image on the left, the analysis showed a negligible correlation among all rooms considered. However, N33 had very little window opening compared to the other flats. After removing N33 from the dataset for this reason, the analysis showed a positive, strong correlation trend. That is, as the WOR increased so did the number of hours over $26^{\circ} \mathrm{C}$. This finding is potentially problematic for the recommendation to open windows to cool down as a heated façade or other nearby surface acting as an external heat source could lead to warm air coming into the building. This, however, does not measure or negate the cooling feeling of a breeze that the occupants may feel. 


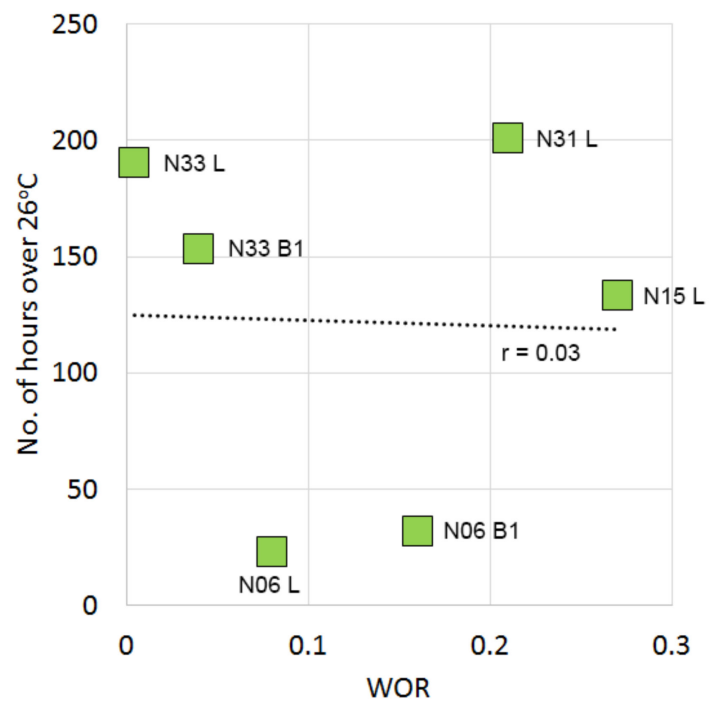

(a)

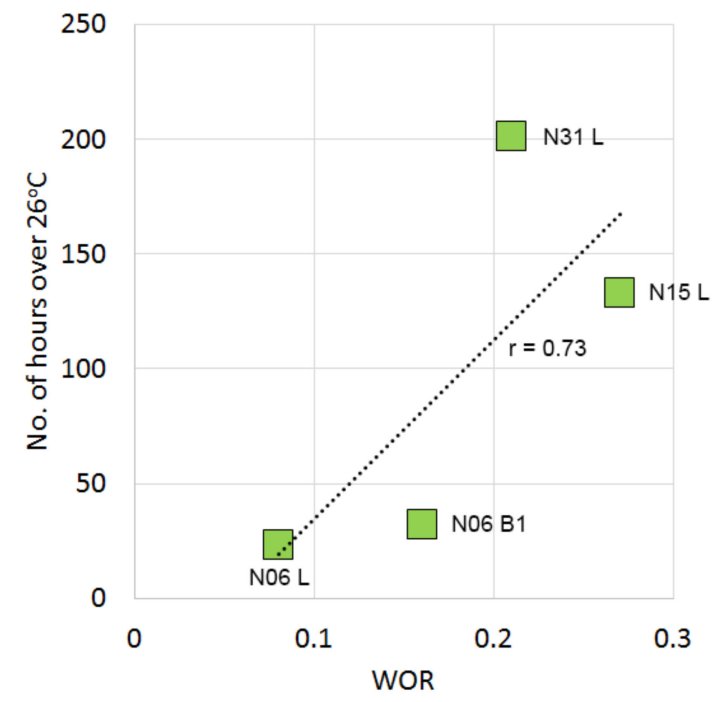

(b)

Figure 13. High temperature hours vs. living room window opening ratio (WOR): (a) Flats N31, N33, N15, N06; (b) Flats N31, N15, N06.

\subsection{Window Opening and Indoor $\mathrm{CO}_{2}$ Concentrations and $\mathrm{RH}$}

In line with the window opening behaviour resulting in higher ventilation rates, indoor $\mathrm{CO}_{2}$ levels in the four flats were found to be low. The mean $\mathrm{CO}_{2}$ levels varied from $429 \mathrm{ppm}$ in the living room of N33 to $725 \mathrm{ppm}$ in the bedroom of the same flat. The threshold of $2000 \mathrm{ppm}$ was surpassed only once in one bedroom of flat N15. Similarly, the mean RH levels varied from $43 \%$ in the living room of N31 to 57\% in the bedrooms of flat N06. None of the four flats experienced RH levels that would be considered too high. Overall, higher indoor temperatures corresponded with lower RH. Table 10 shows the mean and maximum $\mathrm{CO}_{2}$ concentration and $\mathrm{RH}$ difference between the interior and exterior (400 ppm used as exterior base for $\mathrm{CO}_{2}$ ). Figure 14 shows the impact of window opening on the $\mathrm{CO}_{2}$ concentrations in the living rooms of N31 and N06 and Figure 15 shows the impact of window opening on the RH in the living rooms of N31 and N06.

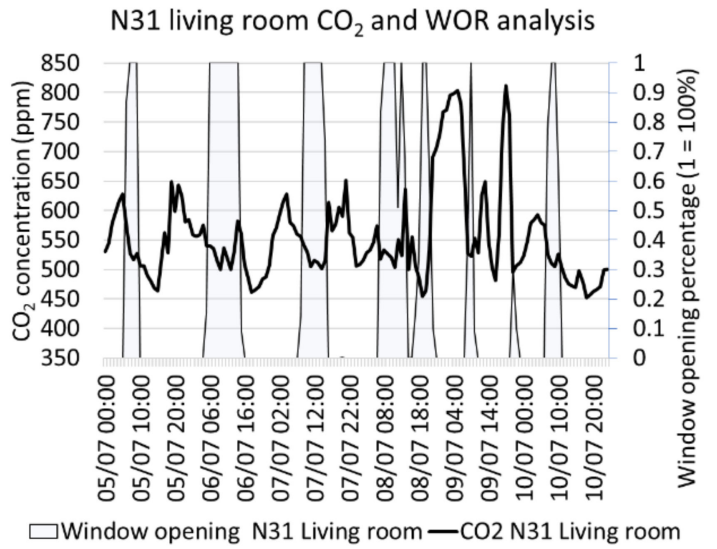

(a)

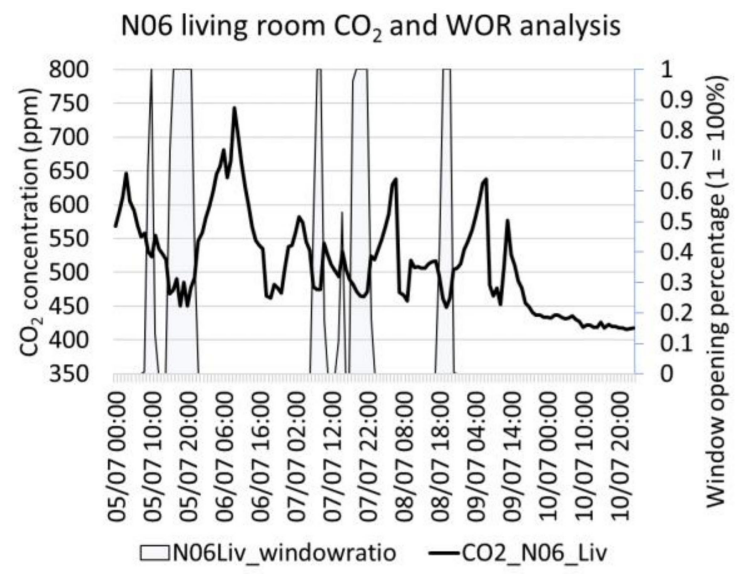

(b)

Figure 14. $\mathrm{CO}_{2}$ concentration and window opening in living rooms: (a) Flat N31; (b) Flat N06. 
N31 living room RH and WOR analysis

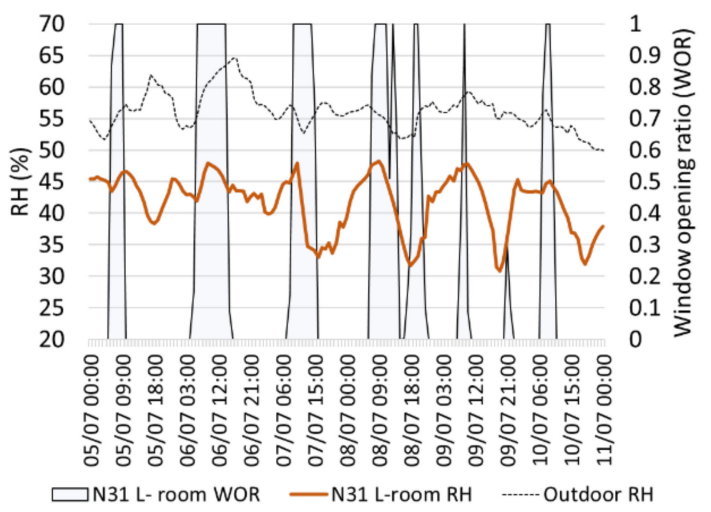

(a)

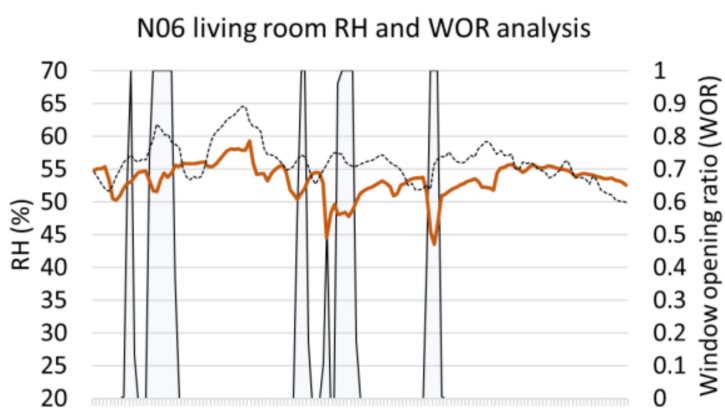

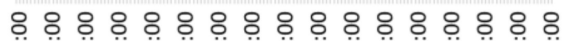

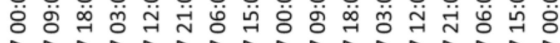

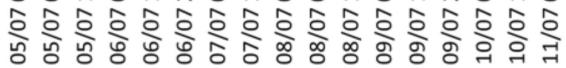

口N06 L- room WOR — N06 L-room RH -....... Outdoor RH

(b)

Figure 15. RH and window opening in the living rooms: (a) Flat N31; (b) Flat N06.

Table 10. Difference in interior and exterior $\mathrm{CO}_{2}$ concentration and $\mathrm{RH}$ data from window opening $(\mathrm{O}=$ open, $\mathrm{C}=$ closed). Note: For most of the time the indoor RH was lower than outdoor; the mean and maximum figures are absolute).

\begin{tabular}{|c|c|c|c|c|c|c|c|c|c|c|c|c|}
\hline \multirow{3}{*}{ WOR (\% of Time) } & \multicolumn{2}{|c|}{$\begin{array}{l}\text { N31 Living } \\
\text { Room }\end{array}$} & \multicolumn{2}{|c|}{$\begin{array}{l}\text { N33 Living } \\
\text { Room }\end{array}$} & \multicolumn{2}{|c|}{ N33 Bedroom 1} & \multicolumn{2}{|c|}{$\begin{array}{l}\text { N15 Living } \\
\text { Room }\end{array}$} & \multicolumn{2}{|c|}{$\begin{array}{l}\text { N06 Living } \\
\text { Room }\end{array}$} & \multicolumn{2}{|c|}{ N06 Bedroom 1} \\
\hline & \multicolumn{2}{|c|}{$0.19(29 \%)$} & \multicolumn{2}{|c|}{$0.005(2 \%)$} & \multicolumn{2}{|c|}{$0.02(5 \%)$} & \multicolumn{2}{|c|}{$0.30(76 \%)$} & \multicolumn{2}{|c|}{$0.11(30 \%)$} & \multicolumn{2}{|c|}{$0.18(47 \%)$} \\
\hline & $\mathrm{O}$ & $\mathrm{C}$ & $\mathrm{O}$ & $\mathrm{C}$ & $\mathrm{O}$ & $\mathrm{C}$ & $\mathrm{O}$ & $\mathrm{C}$ & $\mathrm{O}$ & $\mathrm{C}$ & $\mathrm{O}$ & $\mathrm{C}$ \\
\hline Mean $\mathrm{CO}_{2}(\mathrm{ppm})$ & 168 & 202 & 65 & 79 & 215 & 379 & 240 & 267 & 144 & 165 & 339 & 322 \\
\hline $\operatorname{Max} \mathrm{CO}_{2}(\mathrm{ppm})$ & 341 & 461 & 123 & 297 & 234 & 1161 & 806 & 886 & 537 & 531 & 1196 & 1332 \\
\hline Mean RH (\%) & 11.6 & 11.3 & 10.4 & 8.8 & 12.6 & 4.9 & 5.0 & 4.7 & 4.1 & 1.1 & 1.5 & 3.0 \\
\hline Max RH (\%) & 22.9 & 24.0 & 13.4 & 22.6 & 19.8 & 18.8 & 12.6 & 12.0 & 12.1 & 12.1 & 9.6 & 9.6 \\
\hline
\end{tabular}

The impact of window opening is most apparent on $\mathrm{CO}_{2}$ concentrations in the rooms. Drops in $\mathrm{CO}_{2}$ levels as a result of opening the window can be sharp at times. $\mathrm{RH}$ in flat N31 appears to drop to minimum in the late afternoon/evening (peaking between 4-7 p.m.) corresponding with the time when solar gains are expected to be highest in the WSW facing living room. This is happening regardless of window opening during these times. The mean difference in $\mathrm{RH}$ when windows are open or closed also shows little change. N06 in contrast, has higher RH which is interestingly more closely associated with the external RH despite less window opening.

\subsection{Occupant Experience of the Indoor Environment}

Insights gained from analysing the measured indoor environment were supported by resident perception of the indoor environment during the summer period. The BUS questionnaire survey of the four case study flats revealed that residents perceived the indoor temperature and indoor air in summer to be comfortable and satisfactory. These ratings were however at the higher end of the BUS benchmark for like-dwellings (Figure 16). It is worth noting that the BUS survey was undertaken in 2018 after residents had experienced the summer and winter periods of 2017. The intent was to observe the overall view of the perception of each season.

When asked specifically about the range from too hot to too cold, occupants rated the flats on the hot side of neutral. Additional comments regarding comfort corroborated the findings with residents of flat N06 showing higher levels of satisfaction with the indoor thermal environment. On the other hand, resident in N15 mentioned that the worst aspect about the flat was that it 'gets very warm in the summer'. 


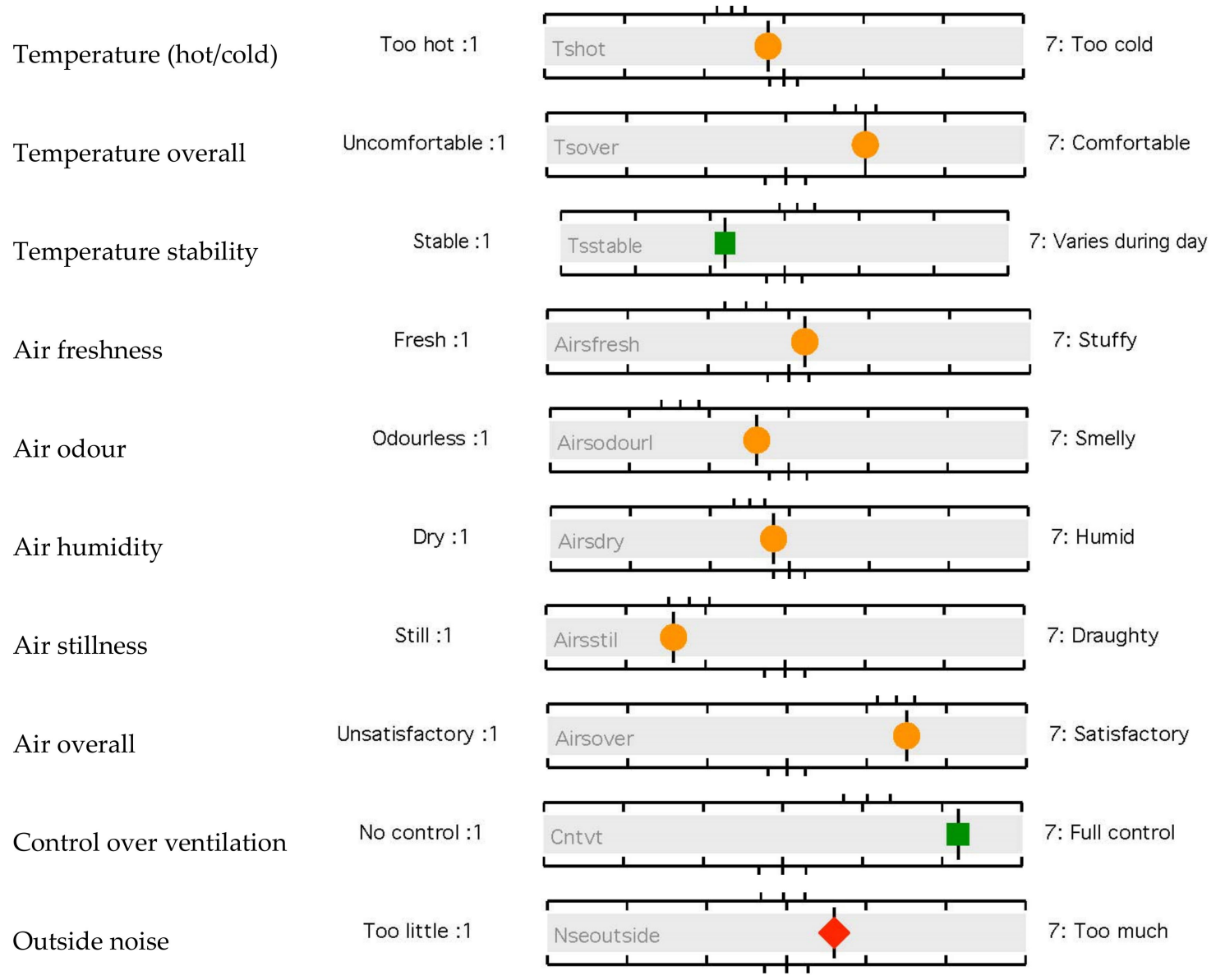

Figure 16. BUS responses for the four case study flats.

Indoor air quality in summer was likewise perceived to be positive but only within the benchmark range. A positive outcome was that control over ventilation was considered highly rated, much above the BUS benchmark, affirming the frequent use of windows for ventilation. Outside noise overall, received a poor rating for being 'too much'. The flats facing the north side are located on a busy road. This mostly affected Flat N15 and some bedrooms in N31 and N33. No direct connection was made to outdoor noise affecting window opening but the following comments were captured:

"Can be a little loud at night" -N15

"Some inevitable car noise—-but acceptable"—N31

\section{Discussion}

The variation in high indoor temperatures and overheating across the four flats was examined through key building characteristics that include: location of the flat in terms of floor level, glazing orientation, exposed surface area floor area ratio (SA/FA), glazing area to floor area ratio (GA/FA), ventilation driven by window opening and surrounding features. The authors are aware that sweeping scientific conclusions about overheating in flats in England or even overheating in flats located in the same development cannot be made, as there are numerous variables which affect internal temperatures. However, there are valuable lessons learnt from the case studies. These case studies provide useful lessons for consideration when designing new or retrofitted flats. As Flyvbjerg [52] states in Five misunderstandings about case-study research, "... formal generalization, whether on the basis of large samples or single cases, is considerably overrated as the main source of scientific progress." [53], p. 226.

It is evident that flats located on the top floor, N33 and N31 experienced high indoor temperatures and significant levels of overheating during the monitoring period. This is in line with previous 
research that found top-floor flats to be at a higher overheating risk than lower-floor flats $[7,37]$. The risk of overheating in the two top floor flats was also confounded by the fact that they had orientations that are difficult to protect with horizontal shading elements [22,53]. While flat N31 had west facing glazing in the most overheated room, flat N33 had east facing glazing. Since east is not as unfavourable an orientation as west in terms of solar gain, being on the top floor may have a more significant influence on the variation in indoor temperatures.

Furthermore, the metrics SA/FA ratio and GA/FA ratio were used to examine the difference in overheating between the two top floor flats. Although flat N31 had west facing glazing, typically more prone to overheating, flat N33 had greater GA/FA ratio and greater solar radiation per area of glazing. This is possibly why flat N31 exhibited the highest maximum temperature (possibly due to the west facing glazing), but N33 experienced a greater extent of 'all hours' static overheating. These findings are in line with a study of the impact of the urban heat island (UHI) in London that showed the effects of built form and other dwelling characteristics appear to be important determinants of variation in high indoor temperatures [54].

Although windows were regularly opened across all four case study flats, this did not contribute to bringing down high indoor temperature hours. This suggests that ventilation through window opening in these specific flat's spatial arrangements may not be effective enough on its own. Lacking most were cross-ventilation, suitable glazing orientation and window shading. Moreover, the effectiveness of window opening is determined by resident preference, which can be an unacceptable option where bugs, dust, smells, lights, noise or fear of unauthorized entry are prevalent [17]. As noted in the BUS survey, two case study flats noted their discontent with outdoor traffic noise. It is evident that having openable windows is not enough for mitigating overheating risk; building design needs to take a holistic approach to ensure that there is provision of adequate cross-ventilation, window shading and window opening is not inhibited by external factors.

In addition to dwelling characteristics, it is likely that local surroundings have some effect on the microclimate that in turn influences indoor temperatures. As seen in Figure 1, the housing development is surrounded by green space and light-coloured surfaces, which are expected to reduce the incident heat on the lower floor flats. This is a strong potential reason why flat N06, that faced a courtyard directly, experienced no overheating.

Although the four case studies are indicative rather than representative, the study has shown that building design features (such as form, orientation, glazing, ventilation, shading, surrounding features) have potentially significant influence on the occurrence of summertime overheating. Lack of such measures may cause occupants to turn to energy-intensive air-conditioning for cooling as the climate warms. Though summertime overheating has been shown to occur in these flats, the features that bring in, capture, and retain heat are beneficial in all other seasons. Any design changes to limit overheating in dwellings should consider all seasons and the position of the sun so as not to limit the beneficial gain outside of summer.

\section{Conclusions}

This study is based on empirical data collected during the summer of 2017 in four new-build modern flats located in a housing development in southeast of England. Analysis of the monitoring data of indoor and outdoor temperature confirmed that summertime overheating was prevalent in most flats, but was most pronounced in flats on top floors, particularly those with roof exposure and glazing orientations towards west. The top floor flats showed much higher variability of indoor temperature compared to flats on lower floors. The mean indoor temperatures in summer varied from $26.5^{\circ} \mathrm{C}$ to $23.9^{\circ} \mathrm{C}$, while the outdoor mean temperature was $19.9^{\circ} \mathrm{C}$. Bedrooms were found to be more prone to overheating than living rooms. Although good $\mathrm{CO}_{2}$ levels were maintained throughout the monitoring period in all the flats since windows were opened regularly, this offered little mitigation to overheating. 
Given that the UK Government is planning to build 300,000 new homes per year, which are expected to be more airtight with better thermal standards, assessment of their summertime overheating risk at the design stage is essential. Designers, developers and planners will need to work together to ensure that new build homes are resilient to overheating, paying special attention to:

- Exposure, SA/FA ratio and GA/FA ratio of top-floor flats

- Solar gain implications of orientation especially west-facing which is also difficult to externally shade.

- Shading elements should be integrated into the fabric as external shading has been shown to be more effective than blinds (internal shading).

- New ways to provide cross-ventilation for flats especially where space is often a limiting factor. This may include features such as fan driven ducted ventilation-to be explored in future research.

- Use of light-coloured surfaces and access to green and blue spaces.

Good passive design will not only prevent overheating, it will also avoid the growth of energy intensive and localized heat producing domestic air-conditioning in the future especially in a warming climate. This should be mandated as part of compliance to Building Regulations.

Author Contributions: Conceptualization, R.G.; Data curation, M.G.; Formal analysis, M.G.; Funding acquisition, R.G.; Investigation, R.G.; Methodology, R.G. and M.G.; Supervision, R.G. All authors have read and agreed to the published version of the manuscript.

Funding: This research received external funding from Innovate UK as part of the I-life research project on Insurance-backed warranty for whole life housing energy performance. (Application no: 55662-413534).

Acknowledgments: We are thankful to residents of the flats for allowing us to study their homes. We are also grateful to Agnese Salvati and Luka Oreskovic for their work in gathering the data used for this study.

Conflicts of Interest: The authors declare no conflict of interest.

\section{References}

1. BEIS; Skidmore, C. UK Becomes First Major Economy to Pass Net Zero Emissions Law: New Target Will Require the UK to Bring All Greenhouse Gas Emissions to Net Zero by 2050. Available online: https://www. gov.UK/government/news/UK-becomes-first-major-economy-to-pass-net-zero-emissions-law (accessed on 30 September 2019).

2. HM Government. The Carbon Plan: Delivering Our Low Carbon Future; Department of Energy and Climate Change: London, UK, 2011; p. 220.

3. Ministry of Housing Communities and Local Government. The Future Homes Standard 2019: Consultation on Changes to Part L (Conservation of Fuel and Power) and Part F (Ventilation) of the Building Regulations for New Dwellings; Ministry of Housing, Communities and Local Government: London, UK, 2019.

4. Blackman, D. The Future Homes Standard: Get Ready for a Domestic Revolution. Available online: https://www. building.co.UK/focus/the-future-homes-standard-get-ready-for-a-domestic-revolution/5103031.article (accessed on 30 April 2012).

5. Palmer, J.; Godoy-Shimizu, D.; Tillson, A.; Mawditt, I. Building Performance Evaluation Programme: Findings from Domestic Projects Making Reality Match Design; Innovate UK: Swindon, UK, 2016.

6. Gupta, R.; Gregg, M.; Passmore, S.; Stevens, G. Intent and Outcomes from the Retrofit for the Future Programme: Key Lessons. Build. Res. Inf. 2015, 43, 435-451. [CrossRef]

7. Beizaee, A.; Lomas, K.J.; Firth, S.K. National Survey of Summertime Temperatures and Overheating Risk in English Homes. Build. Environ. 2013, 65, 1-17. [CrossRef]

8. Gupta, R.; Matt, G.; Robert, I. Meta-Analysis of Summertime Indoor Temperatures in New-Build, Retrofitted, and Existing UK Dwellings. Sci. Technol. Built Environ. 2019, 25, 1212-1225. [CrossRef]

9. Morey, J.; Beizaee, A.; Wright, A. An Investigation into Overheating in Social Housing Dwellings in Central England. Build. Environ. 2020, 176, 106814. [CrossRef]

10. Drury, P.; Lomas, K. No Escape from the Heat? Bedroom Temperatures during England's Hottest Summer. In Proceedings of the 11th Windsor Conference: Resilient Comfort, Windsor, UK, 16-19 April 2020.

11. ZCH. Overheating in Homes-An Introduction for Planners, Designers and Property Owners; Zero Carbon Hub: London, UK, 2012. 
12. Gupta, R.; Gregg, M.; Bruce-Konuah, A. Assessing the Occurrence of Summertime Overheating in Occupied and Unoccupied Low Energy Homes; PLEA: Edinburgh, UK, 2017.

13. Gupta, R.; Matthew, G. Using UK Climate Change Projections to Adapt Existing English Homes for a Warming Climate. Build. Environ. 2012, 55, 20-42. [CrossRef]

14. AECOM. Research into Overheating in New Homes. In Phase 1 Report; AECOM: London, UK, 2019.

15. Armstrong, B.G.; Chalabi, Z.; Fenn, B.; Hajat, S.; Kovats, S.; Milojevic, A.; Wilkinson, P. Association of Mortality with High Temperatures in a Temperate Climate: England and Wales. J. Epidemiol. Community Health 2010, 65, 340-345. [CrossRef] [PubMed]

16. Hajat, S.; Vardoulakis, S.; Heaviside, C.; Eggen, B. Climate Change Effects on Human Health: Projections of Temperature-Related Mortality for the UK during the 2020s, 2050s and 2080s. J. Epidemiol. Community Health 2014, 68, 641-648. [CrossRef]

17. Good Homes Alliance. Overheating in New Homes: Tool and Guidance for Identifying and Mitigating Early Stage Overheating Risks in New Homes; Good Homes Alliance: London, UK, 2019.

18. Gupta, R.; Matt, G. Preventing the Overheating of English Suburban Homes in a Warming Climate. Build. Res. Inf. 2013, 41, 281-300. [CrossRef]

19. McLeod, R.S.; Hopfe, C.J.; Kwan, A. An Investigation into Future Performance and Overheating Risks in Passivhaus Dwellings. Build. Environ. 2013, 70, 189-209. [CrossRef]

20. Lomas, K.J.; Kane, T. Summertime Temperatures and Thermal Comfort in UK Homes. Build. Res. Inf. 2013, 41, 259-280. [CrossRef]

21. Sameni, S.M.T.; Gaterell, M.; Montazami, A.; Ahmed, A. Overheating Investigation in UK Social Housing Flats Built to the Passivhaus Standard. Build. Environ. 2015, 92, 222-235. [CrossRef]

22. Gupta, R.; Matt, G. Care Provision Fit for a Warming Climate. Archit. Sci. Rev. 2017, 60, 275-285. [CrossRef]

23. Roberts, B.M.; Allinson, D.; Lomas, K.J. A Matched Pair of Test Houses with Synthetic Occupants to Investigate Summertime Overheating. J. Sustain. Des. Appl. Res. 2018, 6, 4.

24. Larsen, T.S.; Jensen, R.L. Comparison of Measured and Calculated Values for the Indoor Environment in One of the First Danish Passive Houses. In Proceedings of the 12th Conference of International Building Performance Simulation Association, Sydney, Australia, 14-16 November 2011.

25. Österreicher, D.; Stefan, S. Maintaining Comfortable Summertime Indoor Temperatures by Means of Passive Design Measures to Mitigate the Urban Heat Island Effect-A Sensitivity Analysis for Residential Buildings in the City of Vienna. Urban Sci. 2018, 2, 66. [CrossRef]

26. Ruud, S.H.; Lundin, L.; Sandberg, M.; Nielsen, J.; Wahlström, A.; Törnström, T.; Kovacs, P. Houses without a Traditional Heating System-Results from Two Years of Measurement. In Proceedings of the World Sustainable Building Conference, Tokyo, Japan, 27-29 September 2005.

27. Maivel, M.; Jarek, K.; Targo, K. Field Survey of Overheating Problems in Estonian Apartment Buildings. Archit. Sci. Rev. 2015, 58, 1-10. [CrossRef]

28. CIBSE. Environmental Design Guide A; CIBSE: London, UK, 2006.

29. Tm52 the Limits of Thermal Comfort: Avoiding Overheating in European Buildings; CIBSE: London, UK, 2013.

30. BSI. Bs En 15251:2007 Indoor Environmental Input Parameters for Design and Assessment of Energy Performance of Buildings Addressing Indoor Air Quality, Thermal Environment, Lighting and Acoustics; British Standards Institute: London, UK, 2008.

31. Liu, C.; David, C. Overheating Risk of UK Dwellings under a Changing Climate. Energy Procedia 2015, 78, 2796-2801. [CrossRef]

32. Fletcher, M.J.; Johnston, D.K.; Glew, D.W.; Parker, J.M. An Empirical Evaluation of Temporal Overheating in an Assisted Living Passivhaus Dwelling in the UK. Build. Environ. 2017, 121, 106-118. [CrossRef]

33. Attia, S.; Salvatore, M.C. Impact of Different Thermal Comfort Models on Zero Energy Residential Buildings in Hot Climate. Energy Build. 2015, 102, 117-128. [CrossRef]

34. Salvalai, G.; Jens, P.; Sesana, M.M. Assessing Energy and Thermal Comfort of Different Low-Energy Cooling Concepts for Non-Residential Buildings. Energy Convers. Manag. 2013, 76, 332-341. [CrossRef]

35. Engelmann, P.; Kalz, D.; Salvalai, G. Cooling Concepts for Non-Residential Buildings: A Comparison of Cooling Concepts in Different Climate Zones. Energy Build. 2014, 82, 447-456. [CrossRef]

36. Haggag, M.; Hassan, A.; Elmasry, S. Experimental Study on Reduced Heat Gain through Green Façades in a High Heat Load Climate. Energy Build. 2014, 82, 668-674. [CrossRef] 
37. Vellei, M.; Ramallo-Gonzalez, A.P.; Coley, D.; Lee, J.; Gabe-Thomas, E.; Lovett, T.; Natarajan, S. “Overheating in Vulnerable and Non-Vulnerable Households. Build. Res. Inf. 2017, 45, 102-118. [CrossRef]

38. Wright, D.L.; Haines, V.; Lomas, K.J. Overheating in UK Homes: Adaptive Opportunities, Actions and Barriers. In Windsor Conference: Rethinking Construction; Brotas, L., Ed.; NCEUB: Windsor, UK, 2018; pp. 400-417.

39. CIBSE. Environmental Design: Cibse Guide A; CIBSE: London, UK, 2015.

40. Gupta, R.; Mariam, K. Empirical Assessment of Indoor Air Quality and Overheating in Low-Carbon Social Housing Dwellings in England, UK. Adv. Build. Energy Res. 2016, 10, 46-68. [CrossRef]

41. Baborska-Narożny, M.; Stevenson, F.; Grudzińska, M. Overheating in Retrofitted Flats: Occupant Practices, Learning and Interventions. Build. Res. Inf. 2017, 45, 40-59. [CrossRef]

42. Dengel, A.; Swainson, M. Overheating in New Homes; A Review of the Evidence; Building Research Establishment: Watford, UK, 2012.

43. Pana, E. Summertime Temperatures and Overheating Risk: Does Orientation Affect Comfort in Bedrooms in the UK Context. In Proceedings of the 3rd Conference: People and Buildings, London, UK, 20 September 2013.

44. Morgan, C.; FOSTER, J.A.; Sharpe, T.; Poston, A. Overheating in Scotland: Lessons from 26 Monitored Low Energy Homes. In Proceedings of the International Conference CISBAT 2015 Future Buildings and Districts Sustainability from Nano to Urban Scale, Lausanne, Switzerland, 9-11 September 2015.

45. Morgan, C.; Foster, J.A.; Poston, A.; Sharpe, T.R. Overheating in Scotland: Contributing Factors in Occupied Homes. Build. Res. Inf. 2017, 45, 143-156. [CrossRef]

46. Toledo, L.; Cropper, P.; Wright, A.J. Unintended Consequences of Sustainable Architecture: Evaluating Overheating Risks in New Dwellings. In Proceedings of the PLEA (Passive and Low Energy Architecture) Conference, Los Angeles, CA, USA, 3-5 July 2016.

47. McGill, G.; Sharpe, T.; Robertson, L.; Gupta, R.; Mawditt, I. Meta-Analysis of Indoor Temperatures in New-Build Housing. Build. Res. Inf. 2017, 45, 19-39. [CrossRef]

48. Mitchell, R.; SUKumar, N. Overheating Risk in Passivhaus Dwellings. Build. Serv. Eng. Res. Technol. 2019, 40, 446-469. [CrossRef]

49. Tink, V.; Porritt, S.; Allinson, D.; Loveday, D. Measuring and Mitigating Overheating Risk in Solid Wall Dwellings Retrofitted with Internal Wall Insulation. Build. Environ. 2018, 141, 247-261. [CrossRef]

50. ARUP. Bus Methodology. Available online: http://www.busmethodology.org.UK/ (accessed on 30 October 2018).

51. Lomas, K.J.; Porritt, S.M. Overheating in Buildings: Lessons from Research; Taylor \& Francis: Abingdon, UK, 2017.

52. Flyvbjerg, B. Five Misunderstandings about Case-Study Research. Qual. Inq. 2006, 12, 219-245. [CrossRef]

53. Porritt, S.M.; Cropper, P.C.; Shao, L.; Goodier, C.I. Ranking of Interventions to Reduce Dwelling Overheating During Heat Waves. Energy Build. 2012, 55, 16-27. [CrossRef]

54. Oikonomou, E.; Davies, M.; Mavrogianni, A.; Biddulph, P.; Wilkinson, P.; Kolokotroni, M. Modelling the Relative Importance of the Urban Heat Island and the Thermal Quality of Dwellings for Overheating in London. Build. Environ. 2012, 57, 223-238. [CrossRef]

(C) 2020 by the authors. Licensee MDPI, Basel, Switzerland. This article is an open access article distributed under the terms and conditions of the Creative Commons Attribution (CC BY) license (http://creativecommons.org/licenses/by/4.0/). 